

\section{Sumário}

I. INTRODUÇÃO

The Datasphere and the Law: New Space, New Territories ...................................III Jean-Sylvestre Bergé e Stéphane Grumbach

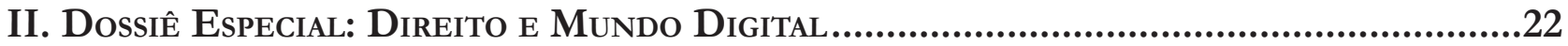

A. Criptomoedas e tecnologia blockchain ......................................................................23

Passado, presente e futuro da CRiptografia forte: DesenVolvimento tecnológico e

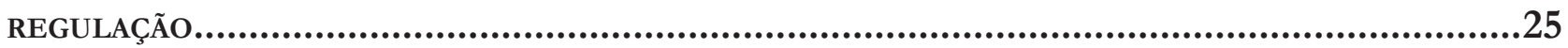
Jacqueline de Souza Abreu

Tratamento JuRídico Das CRIPTOMOEDAS: A DiNÂMiCA DOS BitCOINS E O CRIME DE LAVAGEM

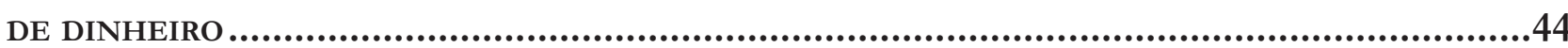
Mariana Dionísio de Andrade

TERRITÓRIO DAS CRIPTOMOEDAS: LIMITES À REGULAMENTAÇÃo ESTATAL QUANTO À CIRCULAÇÃO DE MOEDAS NO CIBERESPAÇO E POSSÍvEIS ALTERNATIVAS ..................................................61 Ranidson Gleyck Amâncio Souza

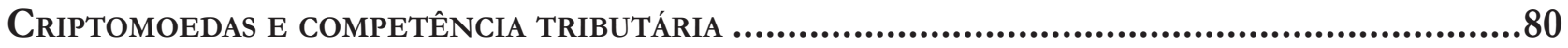
Guilherme Broto Follador

BitCoIn E A (IM)POSSIBILIDAde DE SUA PROIBIÇÃO: UMA VIOLAÇÃo À SOBERANIA Do EsTAdo?106 Rodrigo Valente Giublin Teixeira e Felipe Rangel da Silva

BlockChain e Agenda 2030

Danielle Mendes Thame Denny, Roberto Ferreira Paulo e Douglas de Castro

A reconstruÇão da JURISDição PELO ESPAÇO Digital: REDES SOCIAIS, BLOCKCHAIN E CRIPTOMOEDAS COMO PROPULSORES DA MUDANÇA.

Maria Edelvacy Pinto Marinho e Gustavo Ferreira Ribeiro

B. Proteção de dados e provedores de Internet

O tempo e O espaço. Fragmentos do marco Civil da internet: paradigmas de Proteção DA DIGNIDADE HUMANA 160 Maria Celeste Cordeiro Leite dos Santos e Marilene Araujo 
O PRojeto de Lei de PRoteção de dAdos PEssoais (PL 5276/2016) NO MUNDO do Big DATA: O FENÔMENO DA DATAVEILLANCE EM RELAÇÃo À UTILIZAÇÃO DE METADADOS E SEU IMPACTO NOS DIREITOS HUMANOS ................................................................................... 185

Elias Jacob de Menezes Neto, Jose Luis Bolzan de Morais e Tiago José de Souza Lima Bezerra

DignidADE HUMANA NA WEBESFERA GOVERNAMENTAL BRASILEIRA...................................200 Luciana Cristina Souza

CiberespaÇo E CONTEÚdo OFENSIVO GERAdo POR TERCEIROS: A PROTEÇão DOS DiREITOS DE PERSONALIDADE E A RESPONSABILIZAÇÃo CIVIL DOS PROVEDORES DE APLICAÇÃO, À LUZ DA JURisprudênCIA do Superior Tribunal de JustiçA................................................ 217 Cristiano Colombo e Eugênio Facchini Neto

A responsabilidade CIVIL pelos atos autônomos da INTEligÊnCIA ARTIFICIAL: NOTAS iniciais sobre a resolução do Parlamento Europeu ...........................................239 Thatiane Cristina Fontão Pires

Rafael Peteffi da Silva

SHARENTING, LIBERDADE DE EXPRESSÃO E PRIVACIDADE DE CRIANÇAS NO AMBIENTE DIGITAL: O PAPEL DOS PROVEDORES DE APLICAÇÃo NO CENÁRIO JURÍDICO BRASILEIRO. 256 Fernando Büscher von Teschenhausen Eberlin

THE DICHOTOMY BETWEEN SMART METERING AND THE PROTECTION OF CONSUMER'S PERSONAL DATA IN BRAZILIAN LAW..

Lucas Noura Guimarães

O CYBERBULlying E OS LIMITES DA LIBERDADE DE EXPRESSÃO 295 Janile Lima Viana, Cinthia Meneses Maia e Paulo Germano Barrozo de Albuquerque

O Supremo Tribunal Federal e o discurso de ódio nas redes sociais: exercício de DIREITO VERSUS LIMITES À LIBERDADE DE EXPRESSÃO

Carlo José Napolitano e Tatiana Stroppa

ANÁlise COMPARAdA DE ESTRATÉgIAS DE ENFRENTAMENTO A “REVENGE PORN” PELO MUNDO .... 334 Natália Neris, Juliana Pacetta Ruiz e Mariana Giorgetti Valente

USO INDEVIDO DE REDES SOCIAIS E APLICATIVOS DE MENSAGENS INSTANTÂNEAS NO AMBIENTE LABORAL 
ENSAIO SOBRE A PROMESSA JURÍDICA DO ESQUECIMENTO: UMA ANÁLISE A PARTIR DA PERSPECTIVA DO PODER SIMBÓliCo DE BOURDIEU 368 Joana Machado e Sergio Negri

UMA AGENDA PARA O DIREITO AO ESQUECIMENTO NO BRASIL. 384 Bruno de Lima Acioli e Marcos Augusto de Albuquerque Ehrhardt Júnior

NÃo AdIANTA NEM TENTAR ESQUECER: UM ESTUdo SOBRE O DIREITO AO ESQUECIMENTO...... 412 José Augusto Fontoura Costa e Geraldo Miniuci

A aplicaÇão do direito ao ESQUecimento aos agentes delitivos: uma ANÁlise aCERCA da PONDERAÇÃO ENTRE O DIREITO À IMAGEM E AS LIBERDADES DE EXPRESSÃO E DE INFORMAÇÃO437 Paulo Afonso Cavichioli Carmona e Flávia Nunes de Carvalho Cavichioli Carmona

DiREITO AO ESQUECIMENTO: NA SOCIEDADE INFORMACIONAL HÁ ESPAÇO PARA O EPÍLOGO DA MÁQUINA DE TORTURA KAFKIANA?

Alexandre Antonio Bruno da Silva e Marlea Nobre da Costa Maciel

ESQUECIMENTO, INTERNET E “PREFERÊNCIA” DA INFORMAÇÃO: POSSIBILIDADES DE APLICAÇÃO DA DOUTRINA DOS PREFERRED RIGHTS DA JURISPRUDÊNCIA NORTE-AMERICANA AO CASO BRASILEIRO 484

Maria Vital da Rocha, Isaac Rodrigues Cunha e Karin de Fátima Rodrigues Oliveira

D. Propriedade intelectual 510

Direitos AUtorais E MÚSICA: TECNOLOGIA, DiREITO E REGUlaÇão Marcia Carla Pereira Ribeiro, Cinthia Obladen de Almendra Freitas e Rubia Carneiro Neves

Direito AUTORAL NA CIBERCUlTURA: UMA ANÁLISE Do ACESSO AOS BENS IMATERIAIS A PARTIR DAS LICENÇAS CREATIVE COMMONS 4.0.

Gabriela Maia Rebouças e Fernanda Oliveira Santos

E. Políticas públicas e novas tecnologias.

SALTO DIGITAL NAS POLÍTICAS PÚBLICAS: OPORTUNIDADES E DESAFIOS .561 Marcelo D. Varella, Clarice G. Oliveira e Frederico Moesch

Fostering E-gOVERnMENT IN BRAZIL: A CASE STUdY OF DIGITAL CERTIFICATION ADOPTION.585 Lamartine Vieira Braga

DEMOCRATIZAÇÃo NA ERA Digital: DESAFIOS PARA UM DiÁlOgo CONSCIENTE E IGUALITÁRIO.602 Raquel Cavalcanti Ramos Machado e Laura Nathalie Hernandez Rivera 
REDES SOCIAIS E CROWDSOURCING CONSTITUCIONAL: A INFLUÊNCIA DA CIBERDEMOCRACIA SOBRE A GÊNESE E A INTERPRETAÇÃO DE NORMAS CONSTITUCIONAIS ...................................... 618 Igor Ajouz

MARCo CIVIL DA INTERNET E POLÍTICA PÚbliCA DE TRANSPARÊNCIA: UMA ANÁLISE DA E-DEMOCRACIA E DO COMPLIANCE PÚBLICO.

Juliana Costa Zaganelli e Wallace Vieira de Miranda

Políticas públicas bRasileiras de COMPUTAÇÃo EM NUVEM: ANÁLISE DOCUMENTAL dos RELATÓRIOS DO GLOBAL CLOUD COMPUTING SCORECARD

Lucas dos Santos Costa e Marcos Fernando Machado de Medeiros

O uso monopolista do Big Data POR EMpresas de aplicativos: políticas públicas para UM DESENVOLVIMENTO SUSTENTÁVEL EM CIDADES INTELIGENTES EM UM CENÁRIO DE ECONOMIA CRIATIVA E DE LIVRE CONCORRÊNCIA...................................................................6 672 José Antonio Remedio e Marcelo Rodrigues da Silva

1. Introdução

2. A urbanização das cidades e a sociedade em rede: economia criativa, colaborativa e compartilhada como formas de concretização de funções sociais da cidade.

4. Concorrência e Big Data Business relevantes às Smart Cities: estudo de caso envolvendo a aquisição do Waze pelo Google

5. Considerações finais

Referências

III. OUTROS TEMAS

COMO SALVAR O SISTEMA DE REPERCUSSÃo GERAL: TRANSPARÊNCIA, EFICIÊNCIA E REALISMO NA escolha do Que o Supremo Tribunal Federal vai Julgar.. .696 Luís Roberto Barroso e Frederico Montedonio Rego

Precariedade do sistema penitenciário brasileiro como base temática para a proibição OU LEGALIZAÇÃO DAS DROGAS. 715

Lilian Rose Lemos Rocha e José Eduardo Cardozo

A terceira margem do constitucionalismo republicano: uma Crítica A Frank Michelman. .732

Daniel Barcelos Vargas

Medida PRovisória E CONTROLE DE CONSTITUCIONALIDADE: RELEVÂNCIA, URGÊNCIA E PERTINÊNCIA TEMÁTICA

Clarice G. Oliveira e José Levi Mello do Amaral Júnior 
ОвJETO E CONCEITO DO DIREITO ADMINISTRATIVO: REVISÃo CRÍTICA...................................765 Carlos Bastide Horbach

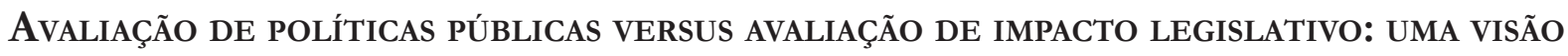
DICOTÔMICA DE UM FENÔMENO SINGULAR

Aparecida de Moura Andrade e Héctor Valverde Santana

LOS AVATARES DEL INTERÉS DEFINIDO EN TÉRMINOS DE PODER EN LA FORMULACIÓN DE LAS POLÍTICAS PÚBLICAS

Louis Valentin Mballa

CONSEQUENCIALISMO JUdicial NA MODUlaÇão DE EFEITOS DAS DECISÕES DECLARATÓRIAS DE INCONSTITUCIONALIDADE NOS JULGAMENTOS DE DIREITO TRIBUTÁRIO 819

Fernando Leal e Daniela Gueiros Dias

JudicializaÇão da SAÚde: A dignidade da PESSOA HuMana E A ATUAÇão do Supremo Tribunal Federal no caso dos medicamentos de alto custo

Fabricio Veiga Costa, Ivan Dias da Motta e Dalvaney Aparecida de Araújo 


\title{
Judicialização da saúde: a dignidade da pessoa humana e a atuação do Supremo Tribunal Federal no caso dos medicamentos de alto custo*
}

\author{
Judicialization of health: the dignity of the \\ human person and the acting of the Supreme \\ Federal Court in the case of high cost medicines
}

\author{
Fabricio Veiga Costa** \\ Ivan Dias da Motta*** \\ Dalvaney Aparecida de Araújo****
}

* Recebido em 24/09/2017

Aprovado em 22/10/2017

** Professor do Programa de Pós-Graduação Stricto Sensu em Proteção dos Direitos Fundamentais da Universidade de Itaúna. Pós-Doutorado em Direito pela Universidade Federal de Minas Gerais; Doutorado e Mestrado em Direito Processual pela Pontifícia Universidade Católica de Minas (PUCMinas); Especialista em Direito Processual, Direito de Família e Direito Educacional pela PUCMinas; Bacharel em Direito pela Universidade Federal de Uberlândia. Email: fvcufu@uol.com.br

*** Professor da Pós-Graduação Stricto Sensu em Direito da UNICESUMAR. Mestrado em Direito das Relações Sociais e Doutorado em Direito das Relações Sociais pela Pontifícia Universidade Católica de São Paulo. Email: ivan.iddm@gmail.com

\section{Resumo}

O objetivo da pesquisa é investigar o fenômeno da judicialização do direito à saúde, no que atine especificamente aos medicamentos de alto custo. Para isso, analisou-se a atuação dos Supremo Tribunal Federal e os critérios hermenêuticos utilizados no julgamento dos casos a ele apresentados, averiguando sua pertinência com o princípio da dignidade da pessoa humana. O artigo cientifico propõe o debate de tema relevante sob o ponto de vista teórico e prático, haja vista a necessidade de esclarecimento jurídico dos critérios hermenêuticos utilizados para o reconhecimento do direito fundamental à saúde. A originalidade do tema decorre dos apontamentos críticos do atual posicionamento do Supremo Tribunal Federal, e dos parâmetros hermenêuticos adotados nas decisões já proferidas. O impacto social pretendido com a pesquisa consiste em garantir a implementação da política pública de medicamentos de alto custo, via atuação jurisdicional, para assegurar a dignidade humana dos pacientes. A presente pesquisa problematiza o tema mas deixa evidente suas limitações, com a intenção de propor novos questionamentos para futuras investigações, especificamente no que tange ao debate de possível colisão entre direitos fundamentais individuais e coletivos. Por meio da pesquisa teórico-bibliográfica e documental, foi possível construir análises temáticas, teóricas, interpretativas e comparativas, que permitiram uma abordagem crítico-epistemológica do tema proposto. Ao final, concluiu-se que a interpretação extensivo-democrática do direito fundamental à saúde garante aos pacientes o acesso aos medicamentos de alto custo, com fundamento na dignidade da pessoa humana.

Palavras-chave: Judicialização. Medicamento de Alto Custo. Saúde. Dignidade da Pessoa Humana. Supremo Tribunal Federal. 


\section{Abstract}

The objective of the research is to investigate the phenomenon of the judicialization of the right to health, in what specifically refers to high cost drugs. For that, the Federal Supreme Court and the hermeneutical criteria used in the trial of the cases submitted to it were analyzed, ascertaining its relevance to the principle of the dignity of the human person. The scientific article proposes the discussion of a relevant topic from a theoretical and practical point of view, given the need for legal clarification of the hermeneutical criteria used for the recognition of the fundamental right to health. The originality of the theme stems from the critical points of the current position of the Federal Supreme Court and the hermeneutical parameters adopted in the decisions already handed down. The social impact sought with the research is to ensure the implementation of the public policy of high cost drugs, through judicial action, to ensure the human dignity of patients. The present research problematizes the theme but leaves its limitations evident, with the intention of proposing new questions for future investigations, specifically regarding the debate of possible collision between individual and collective fundamental rights. Through the theoretical-bibliographic and documentary research, it was possible to construct thematic, theoretical, interpretative and comparative analyzes, which allowed a critical-epistemological approach of the proposed theme. In the end, it was concluded that the extensive democratic interpretation of the fundamental right to health guarantees patients access to high-cost medicines based on the dignity of the human person.

Keywords: Judicialization. High Cost Medication. Cheers. Dignity of human person. Federal Court of Justice

\section{INTRODUÇÃo}

O objetivo do presente estudo consiste em investigar juridicamente a judicialização da saúde sob a perspectiva da dignidade da pessoa humana, analisando-se a atuação do Supremo Tribunal Federal no que tange à concessão de medicamentos e tratamentos de alto custo. Especificamente, pretende-se de contextualizar a judicialização de políticas públicas para, então, em um contexto analítico e crítico, ponderar sobre os parâmetros de concessão dos recursos sanitários no país.

Existe um crescente número de ações judiciais voltadas à efetividade do direito à saúde, em sua maioria ações individuais, pleiteando desde atendimento médico a procedimentos diagnósticos. Esses processos, distribuídos em varas especializadas ou cíveis, revelam uma realidade preocupante para o país: judicialização excessiva da saúde.

Esse fenômeno multifacetado exige respostas imediatas do Poder Judiciário e da Administração Pública, considerando-se, em alguns casos, o risco de vida do pleiteante. Expõem-se, assim, os limites e as possibilidades institucionais da esfera pública. No caso da política de distribuição de medicamentos de alto custo, há que se analisar se se trata de demanda individual ou coletiva e se o medicamento se encontra incorporado ou não pelo Sistema Único de Saúde (SUS). Deve-se ponderar, ainda, se esses fármacos possuem indicações prescritas por órgão regulamentadores, como a ANVISA, ou se constituem métodos experimentais ou paliativos.

Essas indagações devem ser analisadas sob o prisma da dignidade da pessoa humana, posto que tutelar e assegurar o direito à saúde em um contexto social excessivamente injusto e desproporcional na alocação de recursos constitui uma forma de garantir às populações carentes a otimização desse mandamento essencial.

O objeto de pesquisa proposto à análise é juridicamente relevante sob o ponto de vista prático e teórico, uma vez que é cada vez mais necessário esclarecer quais são os critérios hermenêuticos utilizados como parâmetro ao estudo do tema no Estado Democrático de Direito. Nesse sentido, torna-se essencial desmi- 
tificar as abordagens propostas pelo Supremo Tribunal Federal, pois muitas vezes são utilizados critérios dogmáticos de interpretação do direito fundamental à saúde, para excluir pessoas com base na premissa da dogmatização dos direitos coletivos face ao direito individual à saúde.

A temática proposta tem sua delimitação na investigação do protagonismo judicial dos ministros do Supremo Tribunal Federal quanto ao tema "medicamentos de alto custo", que se utilizando de interpretações unilaterais, metajurídicas e solipsistas, impede que todos os sujeitos interessados (afetados pelos efeitos jurídicos do provimento final) participem do debate do mérito processual. Pretende-se demonstrar que a ausência de democraticidade do provimento jurisdicional decorre da inviabilidade de participação dos interessados no debate meritório dos pontos controversos da demanda.

A saúde é um direito fundamental corolário da dignidade humana, cuja interpretação deve ser sistemático-integrativo-democrática, de modo a proporcionar a inclusão e integral proteção da pessoa humana. A implicação prática e social do debate cientifico proposto é evidenciada no sentido de demonstrar que atualmente o Supremo Tribunal Federal tem se utilizado de critérios hermenêuticos para limitar e restringir a efetivação do direito fundamental à saúde, especialmente no que se refere ao acesso aos medicamentos de alto custo.

Pretende-se com o respectivo artigo cientifico identificar aporias e levantar questionamentos que nortearão outras pesquisas cientificas realizadas, especialmente no sentido de demonstrar que direitos individuais e coletivos não podem ser hierarquicamente interpretados, de modo a limitar a proteção integral das pessoas humanas quanto ao direito à saúde. Por isso, a participação de todos os interessados na construção do mérito processual da demanda é essencial para garantir a democraticidade do provimento e a superação do protagonismo judicial no julgamento de ações de medicamentos de alto custo.

Por meio da pesquisa bibliográfica e documental foi possível construir análises temáticas, teóricas, comparativas e críticas do tema de fornecimento de medicamentos de alto custo, delimitando-se o objeto da pesquisa mediante a utilização do método indutivo-dedutivo, partindo-se de uma visão microanalítica (medicamentos e tratamentos de alto custo) em uma direção a uma visão macro (direitos à saúde enquanto mandamento de otimização para se garantir a dignidade da pessoa humana).

\section{A DigNidAde DA PESSOA HUMANA E O ACESSO À SAÚde COMO MANDAMENTOS DE OTIMIZAÇÃo}

As normas de direitos fundamentais devem ser formuladas de modo abstrato ou concreto. Os critérios para identificá-las como normas de direito fundamental advêm de suas disposições. Segundo Alexy ${ }^{1}$, normas de direitos fundamentais são aquelas cujos enunciados estejam presentes no texto da Constituição alemã. No seu entender, tanto regras quanto princípios são normas, vez que ambos dizem o que deve ser e podem ser formulados por meio de expressões deônticas básicas explicitadas pelo dever, pela permissão pela proibição.

Humberto Ávila, de forma assertiva e pontual diferencia regras e princípios:

As regras são normas imediatamente descritivas, primariamente retrospectivas e com pretensão de decidibilidade e abrangência, para cuja aplicação se exige a avaliação da correspondência, sempre centrada na finalidade que lhes dá suporte e nos princípios que lhes são axiologicamente sobrejacentes, entre a construção conceitual da descrição normativa e a construção conceitual dos fatos.

Os princípios são normas imediatamente finalísticas, primariamente prospectivas e com pretensão de complementariedade e de parcialidade, para cuja aplicação demandam uma avaliação da correlação entre o estado de coisas a ser promovido e os efeitos decorrentes da conduta havida como necessária à sua promoção ${ }^{2}$.

1 ALEXY, Robert. Teoria dos direitos fundamentais. Tradução de Virgílio Afonso da Silva. São Paulo: Malheiros, 2011.

2 ÁVILA, Humberto. Teoria dos Princípios: da definição à aplicação dos princípios jurídicos. 4. ed. São Paulo: Malheiros, 2005. p. 129. 
Nesse sentido, os princípios são, assim como as regras, razões para juízos concretos do dever-ser, ainda que de natureza diferente. Assim, a distinção entre regras e princípios pauta-se numa diferenciação entre duas espécies de normas. Mas, o ponto decisivo na distinção entre regras e princípios assenta-se no fato de que princípios são "normas que ordenam que algo seja realizado na maior medida possível dentro das possibilidades jurídicas e fáticas existente. Princípios são, por conseguinte, mandamentos de otimização"3.

Assim, os princípios se distinguem pelo fato serem satisfeitos ou não em graus variados e pelo fato de que a medida devida de sua satisfação depende tanto das possibilidades fáticas quanto das jurídicas. As regras constituem normas que ou são sempre satisfeitas ou não nunca são satisfeitas ${ }^{4}$. Nesse contexto, se a regra é vigente, deve-se fazer exatamente o que ela exige, já que elas contêm "determinações no âmbito daquilo que é fática ou juridicamente possível. Isso significa que a distinção entre regras e princípios é uma distinção qualitativa e não uma distinção de grau. Toda norma é ou uma regra ou um princípio"s.

Ingo Wolfgang Sarlet esclarece a relevância da positivação de princípios e direitos fundamentais no texto constitucional

Mediante a positivação de determinados princípios e direitos fundamentais, na qualidade de expressões de valores e necessidades consensualmente reconhecidos pela comunidade histórica e espacialmente situada, o Poder Constituinte e a própria Constituição transformam-se, de acordo com a primorosa formulação do ilustre mestre de Coimbra, Joaquim José Gomes Canotilho, em autêntica reserva de justiça, em parâmetro de legitimidade ao mesmo tempo formal e material da ordem jurídica estatal ${ }^{6}$.

Visualiza-se a diferença entre princípios e regras quando há conflitos entre princípios e colisões entre regras. Alexy ${ }^{7}$ esclarece que um conflito entre regras só pode ser resolvido se houver uma introdução, em uma das regras, de uma cláusula de exceção que extinga o conflito, ou no caso de, pelo menos, uma das regras for declarada inválida. No caso dos princípios, esclarece o autor que se dois princípios colidem, um dos princípios terá que ceder; não mediante a invalidação do outro tão somente pela precedência de um em face do outro sob determinadas condições.

Nesse sentido, pode-se afirmar que "os direitos fundamentais, como resultado da personalização e positivação constitucional de determinados valores básicos [...] integram, ao lado dos princípios estruturais e organizacionais [...] o núcleo substancial, formado pelas decisões fundamentais, de ordem normativa, revelando que mesmo num Estado constitucional democrático se tornam necessárias”.

"Os direitos fundamentais podem ser estudados projetando-os em diversas dimensões. Essa multidimensionalidade seria uma característica já do próprio modelo epistemológico mais adequado para investigá-lo, como propõe Robert Alexy"9.

Note-se que os princípios possuem pesos diferentes e que os princípios com o maior peso têm precedência. "Os princípios jurídicos fundamentais, dotados também de dimensão ética e política, apontam a direção que se deve seguir para tratar de qualquer ocorrência de acordo com o Direito em vigor, caso ele não contenha uma regra que a refira ou que a discipline suficientemente ${ }^{10}$ ".

Nos dizeres de Lucio Antônio Chamon Junior, "Alexy certamente trata de questões que são fundamentais para uma determinada compreensão da dimensão dos princípios e das regras”. O autor, ainda pontua,

3 ALEXY, Robert. Teoria dos direitos fundamentais. Tradução de Virgílio Afonso da Silva. São Paulo: Malheiros, 2011. p. 90.

4 ALEXY, Robert. Teoria dos direitos fundamentais. Tradução de Virgílio Afonso da Silva. São Paulo: Malheiros, 2011.

5 ALEXY, Robert. Teoria dos direitos fundamentais. Tradução de Virgílio Afonso da Silva. São Paulo: Malheiros, 2011. p. 91.

SARLET, Ingo Wolfgang. A eficácia dos Direitos Fundamentais. 4. ed. Porto Alegre: Livraria do Advogado, 2004. p. 69.

ALEXY, Robert. Teoria dos direitos fundamentais. Tradução de Virgílio Afonso da Silva. São Paulo: Malheiros, 2011.

8 SARLET, Ingo Wolfgang. A eficácia dos Direitos Fundamentais. 4. ed. Porto Alegre: Livraria do Advogado, 2004. p. 70.

9 GUERRA FILHO, Wilis Santiago. Direitos Fundamentais, processo e princípio da proporcionalidade: dos Direitos Fundamentais aos Direitos Humanos. Porto Alegre: Livraria do Advogado, 1997. p. 11.

10 GUERRA FILHO, Wilis Santiago. Direitos Fundamentais, processo e princípio da proporcionalidade: dos Direitos Fundamentais aos Direitos Humanos. Porto Alegre: Livraria do Advogado, 1997. p. 17. 
"apesar de não positivista, Robert Alexy adota a ideia kelseniana de uma norma fundamental sob o argumento de que é necessária para explicar a passagem do plano do ser para o âmbito do dever-ser ${ }^{11}$ ”.

Alexy ${ }^{12}$ desenvolveu ainda uma distinção prima facie das regras e princípios. Estes exigem que algo seja feito dentro das possibilidades jurídicas e fáticas existentes, de modo que eles possuem um caráter prima facie e não um mandamento definitivo. Os princípios concebem razões que podem ser afastadas por razões adversas, ao revés das regras que exigem o cumprimento daquilo que elas ordenam. Com isso, elas possuem uma determinação da extensão de seu conteúdo no aspecto das possibilidades jurídicas e fáticas, o que pode levar à ocorrência de falhas. Se isso ocorrer, fica válido exatamente aquilo que a norma prescreve. As regras "possuem a estrutura lógica que tradicionalmente se atribui às normas do Direito, com a descrição (ou tipificação) de um fato, ao que se acrescenta a sua qualificação prescritiva, amparada de uma sanção"13. Nesse sentido, os princípios fundamentais "são igualmente dotados de validade positiva e de um modo geral estabelecidos na constituição, não se reportam a um fato específico, que se possa precisar com facilidade a ocorrência, extraindo a consequência prevista normativamente ${ }^{14 \%}$.

Quanto aos conflitos referentes à aplicabilidade de regras diante do caso concreto, Alexy realiza uma ponderação entre a teoria dos princípios e a máxima da proporcionalidade, que nos dizeres de Wilis Santiago Guerra Filho, "uma medida é adequada se atinge o fim almejado, exigível, por causar o menor prejuízo possível é finalmente, proporcional em sentido estrito, se as vantagens que trará superarem as desvantagens ${ }^{15}$ ”. Afirma que a natureza dos princípios alude à máxima da proporcionalidade, de modo que as três dimensões desta - a adequação, a necessidade (princípio de meio menos gravoso) e a proporcionalidade em sentido estrito (princípios do sopesamento propriamente dito) - deriva dessa natureza principiológica ${ }^{16}$.Em suas palavras:

Princípios são mandamentos de otimização em face das possibilidades jurídicas e fáticas. A máxima da proporcionalidade em sentido estrito, ou seja, exigência de sopesamento, decorre da relativização em face das possibilidades jurídicas. Quando uma norma de direito fundamental com caráter de princípio colide com um princípio antagônico, a possibilidade jurídica para a realização dessa norma depende do princípio antagônico. Para se chegar a uma decisão é necessário um sopesamento nos termos da lei de colisão ${ }^{17}$

Visualiza-se que a tese central da obra de Alexy (2008) refere-se ao fato de os direitos fundamentais possuírem natureza de princípios e consagrarem-se, portanto, como mandamentos de otimização. A norma fundamental proposta por Alexy possui três tarefas fundamentais: "a) transformar uma categoria do ser - o socialmente eficaz - em um dever-ser - o juridicamente válido; b) determinar quais são os critérios daquilo que se entende por Direito; c) e também criar uma ideia de unidade de sistema, já que todas as normas teriam sua validade, em última instância, na norma fundamental ${ }^{18}$.

A dignidade da pessoa humana é o fundamento garantidor do direito à saúde do cidadão, ainda que em medicamentos de alto custo, resulta em um princípio prima facie. Contudo, a reserva do possível vem

11 CHAMON JUNIOR, Lúcio Antônio. Terium Non Datur: pretensões de coercibilidade e validade em face de uma Teoria da Argumentação Jurídica no marco de uma compreensão procedimental do Estado Democrático de Direito. Jurisdição e Hermenêutica Constitucional. Coordenação Marcelo Cattoni. Belo Horizonte: Mandamentos, 2004. p. 100-101.

12 ALEXY, Robert. Teoria dos direitos fundamentais. Tradução de Virgílio Afonso da Silva. São Paulo: Malheiros, 2011.

13 GUERRA FILHO, Wilis Santiago. Direitos Fundamentais, processo e princípio da proporcionalidade: dos Direitos Fundamentais aos Direitos Humanos. Porto Alegre: Livraria do Advogado, 1997. p. 17.

14 GUERRA FILHO, Wilis Santiago. Direitos Fundamentais, processo e princípio da proporcionalidade: dos Direitos Fundamentais aos Direitos Humanos. Porto Alegre: Livraria do Advogado, 1997. p. 17.

15 GUERRA FILHO, Wilis Santiago. Direitos Fundamentais, processo e princípio da proporcionalidade: dos Direitos Fundamentais aos Direitos Humanos. Porto Alegre: Livraria do Advogado, 1997. p. 28.

16 ALEXY, Robert. Teoria dos direitos fundamentais. Tradução de Virgílio Afonso da Silva. São Paulo: Malheiros, 2011.

17 ALEXY, Robert. Teoria dos direitos fundamentais. Tradução de Virgílio Afonso da Silva. São Paulo: Malheiros, 2011. p. 117.

18 CHAMON JUNIOR, Lúcio Antônio. Terium Non Datur: pretensões de coercibilidade e validade em face de uma Teoria da Argumentação Jurídica no marco de uma compreensão procedimental do Estado Democrático de Direito. Jurisdição e Hermenêutica Constitucional. Coordenação Marcelo Cattoni. Belo Horizonte: Mandamentos, 2004. p. 102. 
apresentando caminhos diversos apontando para o interesse da coletividade, contrariando a interpretação extensivo-integrativo-democrática dos direitos fundamentais como locus de inclusão e proteção integral da dignidade da pessoa humana. "Conceber o direito à saúde apenas, segundo seu aspecto coletivo, significa se-

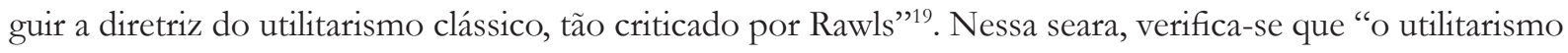
defende que a sociedade atenderia à exigência de justiça "quando suas instituições mais importantes estão planejadas de modo a conseguir o maior saldo líquido de satisfação obtido a partir da soma das participações individuais de todos os seus membros" $" 20$.

"A previsão do direito à saúde como direito fundamental social, cujo acesso deve ser universal, igualitário e gratuito, configurando dever do Estado e direito de todos os cidadãos, ocasiona a reconfiguração da saúde pública de forma a garantir a prestação de bens, utilidades e serviços necessários à sua fruição ${ }^{21 "}$.

Portanto, repensar esses mecanismos de concessão de medicamentos de alto custo enquanto mandamento de otimização tornou-se necessário. Assim, realizar uma releitura dicotômica dos direitos fundamentais individuais e coletivos sob a perspectiva da dignidade da pessoa humana é estritamente necessário na abordagem do presente tema. "Exige-se nova postura do aplicador do direito de uma forma geral e, especialmente, do Poder Judiciário, que não pode se omitir na concretização dos direitos fundamentais. É necessário deixar de lado o perfil que privilegia abordagens dogmáticas e formais ${ }^{22}$ ". Com isso, torna-se possível estruturar a compreensão do direito social à saúde enquanto preceito fundamental, de forma a analisar a judicialização e seus efeitos enquanto veiculadores de promoção social.

A dignidade da pessoa humana constitui o mandamento base de todo o ordenamento jurídico. Esse princípio irradia os demais, uma vez que somente por meio dele se pode concretizar os direitos fundamentais do indivíduo. Trata-se de um princípio que não se restringe a uma declaração ou postulado filosófico. Enquanto mandamento norteador do ordenamento jurídico, a dignidade da pessoa humana possui natureza dúplice, já que deve ser vista como um postulado normativo, considerando que ela serve para indicar a forma como as demais normas devem ser feitas e aplicadas e, enquanto princípio, nenhuma norma pode feri-lo.

A dignidade humana reflete um conceito ambíguo e ainda em construção, assim como os direitos humanos em si. Nesse contexto, é importante esclarecer que a dignidade humana não constitui, em si, como uma construção inata decorrente de proposições jusnaturalistas, uma vez que se trata de um valor jurídico objeto de construção hermenêutica no Estado Democrático de Direito. O texto da Constituição brasileira de 1988 traz proposições jurídicas que legitimam a interpretação extensivo-sistemática dos direitos fundamentais voltada a inclusão, igualdade e ampla proteção jurídica da pessoa humana, tanto sob o ponto de vista individual quanto coletivo.

Sob o viés da filosofia, a dignidade humana liga-se ao antropocentrismo kantiano. Para esse filósofo, o homem enquanto centro do universo possui caráter racional e daí vem sua dignidade. O homem constituiu um fim em si mesmo, de modo que a dignidade deve ser analisada a partir do caso concreto, não se podendo defini-la de maneira global, já que, com a evolução da sociedade, a fórmula homem-objeto, poderia não ser suficiente para proteger todas as violações e assegurar proteção eficiente. Em seu entender, deve-se vislum-

19 MARTINS, Urá Lobato. A judicialização das políticas públicas e o direito subjetivo individual à saúde, à luz da teoria da justiça distributiva de John Rawls. Revista Brasileira de Políticas Públicas, v. 5, Número Especial, 2015. Disponível em: <file:///C:/Users/ Fabricio/Downloads/3020-15496-1-PB.pdf>. Acesso em: 09 out. 2017. p. 319.

20 MARTINS, Urá Lobato. A judicialização das políticas públicas e o direito subjetivo individual à saúde, à luz da teoria da justiça distributiva de John Rawls. Revista Brasileira de Políticas Públicas, v. 5, Número Especial, 2015. Disponível em: <file:///C:/Users/ Fabricio/Downloads/3020-15496-1-PB.pdf>. Acesso em: 09 out. 2017. p. 319.

21 MOURA, Emerson Affonso da Costa Moura; ORDACGY, Fabrizia da Fonseca Passos Bittencourt. Direito à Saúde, políticas públicas do Sistema Único de Saúde e acesso ao serviço público hospital e ambulatorial. Revista Brasileira de Políticas Públicas. v. 4, n. 1, jan./jun. 2014. Disponível em: <file:///C:/Users/Fabricio/Downloads/2628-13625-1-PB.pdf>. Acesso em: 09 out. 2017. p. 54. 22 MATIAS, João Luis Nogueira; MUNIZ, Águeda. O poder judiciário e a efetivação do direito à saúde. Revista Brasileira de Politicas Públicas, v. 5, n. 1, jan./jun. 2015. Disponível em: <file:///C:/Users/Fabricio/Downloads/3377-15381-2-PB.pdf>. Acesso em: 09 out. 2017. 
brar a dignidade, dependendo da relação em que a pessoa era colocada em condições de objeto por vontade própria, sem que a sua dignidade ou sua condição de pessoa fosse ofendida ${ }^{23}$.

Note-se que a dignidade, no tocante à fundamentalidade jurídica, pode ser observada sob três perspectivas diversas. Sob o consenso substantivo, observa-se uma orientação no sentido do direito interno e outra no direito internacional. No caso do direito brasileiro, verifica-se que a dignidade foi alçada ao valor central pelo texto constitucional vigente. No plano internacional, conquanto se discuta quais os meios de proteção da dignidade humana, há certo consenso no que diz respeito dela firmar-se sobre o bem-estar do homem como fim máximo do Estado, que deve reconhecer direitos básicos a seus nacionais ${ }^{24}$.

A outra perspectiva parte de um conjunto variado de formulações teóricas que congregam dois fatores: a crença de que em uma realidade plural, como a contemporânea, não é possível apurar consensos materiais e também empregá-los para legitimar decisões que afetem a sociedade política. Nesse contexto, essa legitimação só poderá decorrer da correção e qualidade dos procedimentos, por meio dos quais tais decisões são apuradas e não do conteúdo das decisões propriamente ditas. Assim, embora numa lógica diversa, a teoria procedimentalista preconiza que os direitos materiais básicos são pressupostos elementares para a dignidade humana ${ }^{25}$.

Baseando-se nas condições materiais e na própria fundamentabilidade jurídica, o texto constitucional reconhece eficácia positiva ou simétrica às faixas que compõem o núcleo da dignidade humana, especialmente a primeira (condições materiais), vislumbrada na exigibilidade da prestação positiva. É que o chamado mínimo existencial compõe as condições materiais básicas para a existência do indivíduo, compondo uma fração nuclear que enseja a eficácia jurídica positiva. Isso porque:

Em primeiro lugar, do ponto de vista jusfilosófica, e para uma sociedade como a contemporânea, que confia nos postulados humanistas e na democracia, a dignidade da pessoa (incluído aí seu aspecto material) constitui o valor mais fundamental. Em segundo lugar, é possível falar de um consenso material acerca da prioridade do homem e de sua dignidade tanto no direito interno especialmente após a Constituição de 1988, como na ordem internacional, ainda que neste último caso, o consenso possa ser apenas teórico em vários pontos. A fundamentalidade jurídica do princípio também pode ser extraída das concepções procedimentalistas (pela qual a legitimidade das decisões decorre da correção do processo deliberativo, já que não é possível apurar consensos matérias abrangentes na sociedade plural, contemporânea), uma vez que se adote como premissa a igualdade dos indivíduos ${ }^{26}$.

Sob a ótica do texto constitucional, a dignidade humana tornou-se, pois, o mandamento fundante da ordem jurídica e a principal finalidade do Estado. Logo, "a dignidade é um piso vital mínimo imposto pela Carta Magna como garantia da possibilidade de realização histórica e real da dignidade da pessoa humana no meio social ${ }^{27}$ ". Sob esse resguardo da dignidade encontram-se a segurança, a saúde, a educação e outros direitos elementares que devem ser positivados pelo Estado. Para atender a essa essencialidade, os valores da dignidade vão além da ideia de patrimônio, eles perpassam as dimensões de direitos (em suas quatro gerações) e os ideais de justiça. Ele se funda eminentemente sobre os direitos fundamentais. Enquanto princípio fundamental, a discussão do conceito de dignidade ultrapassa essas gerações de direito, firmando-se como mandamento-base a partir do reconhecimento dos direitos fundamentais alcançados pelos valores idealizados pela população.

Nessa perspectiva, somente se pode garantir a dignidade da pessoa humana se aos indivíduos tiver assegurados seus direitos fundamentais previstos nos artigos $1^{\circ}, 3^{\circ}$ e $5^{\circ}$ e também os direitos sociais do artigo

23 KANT, Immanuel. Fundamentação da metafísica dos costumes. Tradução de Leopoldo Halzbach. São Paulo: Martin Claret, 2003.

24 BARCELLOS, Ana Paula de. A eficácia jurídica dos princípios constitucionais: o princípio da dignidade da pessoa humana. 3. ed. Rio de Janeiro: Renovar, 2011.

25 BARCELLOS, Ana Paula de. A eficácia jurídica dos princípios constitucionais: o princípio da dignidade da pessoa humana. 3. ed. Rio de Janeiro: Renovar, 2011.

26 BARCELLOS, Ana Paula de. A eficácia jurídica dos princípios constitucionais: o princípio da dignidade da pessoa humana. 3. ed. Rio de Janeiro: Renovar, 2011. p. 292.

27 FIORILlo, Celso Antonio Pacheco. Curso de direito ambiental brasileiro. 12. ed. rev. atual. e ampl. São Paulo: Saraiva, 2011. p. 20. 
$6^{\circ}$, todos da Constituição Federal. Como o princípio da dignidade volta-se aos direitos sociais, a falta de condições materiais mínimas ao homem, prejudica o exercício da liberdade, devendo o Estado não apenas coibi-la, mas proteger ativamente a vida humana, sendo esta a própria razão de ser do Estado ${ }^{28}$.

Esse é o fundamento central do mandamento da reserva do mínimo existencial, segundo o qual a se a pessoa mediana consegue ter uma vida digna sem precisar do bem em questão, este bem não pertence ao direito da dignidade. Dentre o resguardo desse princípio não envolve apenas bens patrimoniais ou integridade física da pessoa humana, mas, sobretudo, sua integridade moral, sentimental, psíquica. Como desdobramento de seus fundamentos e consectários lógicos, observe-se que a prestação positiva de direitos por parte do Estado deve ocorrer de forma a se garantir essa proteção à liberdade, à cidadania, ao bem-estar social, à saúde, à propriedade, à segurança.

A essa pluralidade de interesses, como forma de resguardar a dignidade da pessoa humana, deve o Poder Público cumprir sua obrigação natural positiva de garantir o acesso de seu nacional à saúde, de forma plena e eficaz. Isso porque, tutelar e assegurar esse direito elementar de forma coletiva ou individual implica em assegurar o mínimo necessário para a proteção da dignidade da pessoa humana. Esse mister se torna ainda mais necessário ante um sistema social excludente e desproporcional no que tange à repartição de riquezas, devendo o Estado utilizar seu aparelhamento estatal e garantir a saúde pública de modo mais consectário com as necessidades sociais de toda sua população indistintamente.

Com relação à judicialização do direito à saúde, "tem o Judiciário uma difícil missão: buscar soluções para as crescentes demandas sanitárias, ponderando os valores da democracia, da dignidade da pessoa humana, da fundamentalidade do direito à saúde, da limitação orçamentária, da discricionariedade administrativa e da cautela ${ }^{29} "$, de modo a assegurar a proteção ampla e integral da pessoa humana.

\section{DiReITo À SAÚde COMO diReITO FUNDAMENTAL DE TOdOS}

O texto constitucional vigente foi construído a partir da proposição jusfilosófica norteadora da dignidade da pessoa humana e, consequentemente, possui em seu arcabouço normativo dispositivos referentes aos direitos fundamentais nas suas mais variadas gerações. Como reflexo disso, temos o reconhecimento da carga ideológico-democrática da garantia do mínimo existencial aos brasileiros. A esse preceito, resguarda-se o direito à saúde, que constitui um direito fundamental de natureza social, individual e coletiva, cujas diretrizes e garantias são estabelecidas na Constituição. A saúde representa, assim, um direito social e, como tal, institui-se como direito de todos e dever do Estado. O reconhecimento de sua natureza social, dimensão coletiva e individual decorre de extenso processo histórico de construção da teoria dos direitos fundamentais ao longo dos paradigmas dos Estados Liberal, Social e Democrático de Direito.

"Retomando a ideia do Estado como uma empresa prestadora de serviços públicos, há que se discorrer sobre o dever estatal de alocar da melhor forma possível os recursos públicos, tanto no que diz respeito ao custeio de seus serviços, quanto à concretização de direitos ${ }^{30}$ ".

O reconhecimento e a efetivação dos direitos fundamentais previstos no plano constituinte e instituinte, especialmente o direito fundamental à saúde, constitui pressuposto da proteção igual da dignidade humana, corolário do exercício da cidadania.

28 BARCELLOS, Ana Paula de. A eficácia jurídica dos princípios constitucionais: o princípio da dignidade da pessoa humana. 3. ed. Rio de Janeiro: Renovar, 2011.

29 DIAS, Maria Socorro de Araújo et al. Judicialização da saúde pública brasileira. 135. Revista Brasileira de Políticas Públicas, v. 6, n. 2, out. 2016. Disponível em < file:// C:/Users/Fabricio/Downloads/4012-19241-1-PB.pdf>. Acesso em 09 out. 2017.

30 FARO, Júlio Pinheiro. Políticas públicas, deveres fundamentais e concretização de direitos. Revista Brasileira de Politicas Públicas, v. 3, n. 2, jul./dez. 2013. Disponível em: <file:///C:/Users/Fabricio/Downloads/2161-12654-1-PB.pdf>. Acesso em: 09 out. 2017. p. 259. 
Os percursos da saúde pública no Brasil tem início no XIX com a vinda da Corte portuguesa. Nessa época o governo brasileiro realizava algumas ações de combate à lepra e à peste e controle sanitários nos portos e ruas. Contudo, somente no período de 1870 e 1930, que se pode dizer que o Estado praticara atuações mais efetivas nesse campo, como a adoção do modelo "campanhista" (caracterizado pelo uso corrente da autoridade e da força policial) que, apesar das críticas abusivas, obteve sucessos no controle de doenças epidêmicas. As ações de modelos curativos ficavam reservadas aos serviços privados e à caridade ${ }^{31}$.

A estruturação básica do sistema de saúde pública no Brasil ocorreu em 1930 com a criação do Ministério da Educação e Saúde Pública, dos Institutos de Previdência (IAPs) que ofereciam serviços de saúde de caráter curativo, ligados aos profissionais que possuíam ligação com esses institutos. No período ditatorial brasileiro, houve a unificação dos antigos institutos e a criação do Instituto nacional da Previdência Social (INPS) estendendo-se aos empregados urbanos (com carteira assinada), enquanto contribuinte, tratamentos na rede pública de saúde. Essa limitação inviabilizava o atendimento dos não integrantes ao modelo empregatício $^{32}$.

Com o fim do regime militar e a ascensão da Constituição de 1988, a prestação do serviço público de saúde passou a constituir direitos de todos. Em seu artigo 196, o texto constitucional reconhece que a saúde é "direito de todos e dever do Estado", além de instituir o "acesso universal e igualitário às ações e serviços para sua promoção, proteção e recuperação". A promulgação do texto da Constituição brasileira de 1988, ao instituir o Estado Democrático de Direito, elevou a saúde a um direito fundamental social, de natureza individual e coletiva, cabendo ao Estado promover a efetivação e o exercício de tal direito a todos os cidadãos indistintamente, de modo a utilizá-lo como parâmetro de inclusão da pessoa humana. No texto constitucional consagrou-se:

[...] o direito universal à saúde e as obrigações de financiamento pra cada nível de governo, assim como o papel de cada nível; regulamentou-se a relação como o sistema privado de saúde e, finalmente, instituise como princípio constitutivo do SUS a participação da comunidade. Para garantir essa participação foram definidos, constitucionalmente, vários dispositivos de controle social ${ }^{33}$.

É importante esclarecer, nesse contexto, que "ao tratar do direito à saúde, a Lei Fundamental consignou a sua efetivação à implementação de políticas públicas, a serem custeadas com recursos oriundos do orçamento da seguridade social ${ }^{34 \prime}$.

Como forma de dimensionar e estabelecer os parâmetros da amplitude do direito à saúde, o texto constitucional de 1988 estabeleceu as competências para legislar sobre proteção e defesa da saúde. De forma concorrente, compete à União, aos Estados e aos Municípios a legislar sobre saúde e, de modo comum, elaborar e implementar políticas públicas em matéria de saúde. Em matéria legislativa, à União foi atribuída a competência para o estabelecimento de regras gerais, ao Estado, criar normas suplementares e, aos Municípios, legislar sobre assuntos de interesse local. Nestes termos, tem-se que as competências constitucionalmente atribuídas para ações e serviços voltados à saúde são repartidas aos entes federados, de modo que, a União e os Estados contribuem técnica e financeiramente, ao passo que os Municípios executam os serviços por meio da descentralização.

31 BARROSO, Luiz Roberto. Da falta de efetividade à judicialização excessiva: direito à saúde, fornecimento gratuito de medicamentos e parâmetros para a atuação judicial. Revista da Procuradoria Geral da República. Porto Alegre, v. 31, n. 66, p. 89-114, jul./ dez. 2007.

32 BARROSO, Luiz Roberto. Da falta de efetividade à judicialização excessiva: direito à saúde, fornecimento gratuito de medicamentos e parâmetros para a atuação judicial. Revista da Procuradoria Geral da República, Porto Alegre, v. 31, n. 66, p. 89-114, jul./ dez. 2007.

33 ROCHA, Aristides Almeida; CESAR, Chester Luiz Galvão; RIBEIRO, Helena. Saúde Pública: Bases conceituais. 2. ed. São Paulo: Atheneu, 2013. p. 119.

34 PEREIRA, Fernanda Tercetti Nunes. Ativismo Judicial e Direito à Saúde: a judicialização das políticas públicas de saúde e os impactos da postura ativista do Poder Judiciário. Revista Brasileira de Políticas Públicas. v. 5, Número Especial, 2015. Disponível em: <file:///C:/Users/Fabricio/Downloads/3096-15493-1-PB.pdf>. Acesso em: 09 out. 2017. p. 293. 
Assim, como todos os entes são considerados competentes, deve haver cooperação entre eles para que haja equilíbrio do desenvolvimento e do bem-estar no país ${ }^{35}$ (art. 23, CR/88). Essa atribuição de competência comum remete-se à imperiosidade do direito à saúde e não a superposição entre a atuação dos entes federados. Como forma de regulamentação dessas competências, adveio a lei 8.080 de 1990, que definiu a estrutura e modelo operacional do SUS, bem como as atribuições de cada ente federado.

A lei 8.080 de 1990, em seus artigos 16 a 18, enunciam que compete à União as atividades de caráter normativo, de controle e fiscalização, assim como a de descentralizar para os Estados e Municípios os serviços e ações de saúde de alcance dos mesmos ${ }^{36}$. Assim, aos Estados e Municípios competem planejar, organizar, controlar, avaliar e executar ações e serviços de saúde em suas respectivas áreas de abrangência. Aos Estados, no entanto, cumpre descentralizar, por conseguinte em segundo grau, para os municípios serviços e ações de saúde. No âmbito municipal, conforme preconiza os art. 30, VII, juntamente com o art. $7^{\circ}$, IX da Lei 8.080/90, fixa-se a competência para a prestação do atendimento à saúde da sociedade, atendendo a descentralização dos serviços.

Vislumbra-se, pois, que no contexto brasileiro, a promoção do direito à saúde constitui dever precípuo do Estado, mediante esforços comuns a serem empregados por todos os entes da federação. Assim, enquanto direito social, a saúde, assim como os demais direitos desse âmbito, remetem à prestações positivas proporcionadas pelo Estado, de forma direta ou indireta, que possibilitam melhores condições de vida aos mais vulneráveis, buscando igualizar situações sociais desiguais. Elas "valem como pressupostos do gozo de direitos individuais na medida que criam condições materiais mais propícias no auferimento da igualdade real, o que, por sua vez, proporciona condição mais compatível com o exercício do direito de liberdade ${ }^{37}$.

No contexto do Estado Democrático de Direito há uma promoção da dignidade da pessoa humana, de modo que o exercício do direito à saúde implica no exercício de uma vida digna. Mello acentua que:

A saúde é direito constitucional de primeira geração, por dizer respeito à incolumidade que o Estado há de segunda geração porque o Estado é obrigado a exercer ações que sejam necessárias para proteger as pessoas como direito de terceira geração o estado permite que o direito à saúde seja exercido mediante ações coletivas ${ }^{38}$.

Os direitos sociais possuem dupla dimensão de eficácia: prestacional e defensiva. Esta alude ao fato de que tanto a sociedade como o Estado abstenham-se de adotar medidas que possam lesionar ou ameaçar bens protegidos juridicamente e com eles possuam relação. Já aquela, de natureza positiva, refere-se às atribuições de deveres comissivos, de forma a promover e garantir a sustentabilidade da saúde. Assim, a eficácia defensiva implica numa abstenção a ser feita pelo Poder Público e indivíduos no tocante à vulnerabilidade da saúde, ao passo que a eficácia prestacional refere-se a ações positivas de promoção material para o exercício do direito à saúde. Nesse contexto, explica Sarlet (2001) que:

$\mathrm{Na}$ assim chamada dimensão negativa, ou seja, dos direitos fundamentais como direitos negativos (ou direitos de defesa), basicamente isto quer significar que a saúde, como bem jurídico fundamental, encontra-se protegida contra qualquer agressão de terceiros. Ou seja, o Estado (assim como os demais particulares) tem o dever jurídico de não afetar a saúde das pessoas, de nada fazer (por isto direitos negativo) no sentido de prejudicar a saúde ${ }^{39}$.

35 BRASIL. Constituição (1988). Constituição da República Federativa do Brasil. 12. ed. São Paulo: Revista dos Tribunais, 2017.

36 BRASIL, Lei n. 8.080, de 19 de setembro de 1990. Dispõe sobre as condições para a promoção, proteção e recuperação da saúde, a organização e o funcionamento dos serviços correspondentes e dá outras providências. Disponível em: <http://www.planalto.gov. br/ccivil_03/leis/L8080.htm>. Acesso em: 20 set. 2017.

37 SILVA, Virgílio Afonso da. A constitucionalização do direito: os direitos fundamentais nas relações entre particulares. São Paulo: Mandamentos, 2008. p. 286-287.

38 MELO, José Tarcísio de Almeida. Direito Constitucional do Brasil. 30. ed. rev e atual. Belo Horizonte: Del Rey, 2014. p. 1139.

39 SARLET, Ingo Wolfgang. Dignidade da pessoa bumana e direitos fundamentas na Constituição Federal de 1988. Porto Alegre: Livraria do Advogado, 2001. p. 100. 
$\mathrm{Na}$ visão de Canotilho ${ }^{40}$, o direito à saúde possui quatro formulações: normas de organização, como garantias institucionais, como direitos subjetivos públicos e como normas programáticas. A partir dessa compreensão, Sarmento ${ }^{41}$ sustenta que o direito à saúde no ordenamento brasileiro encontra-se positivado em normas de natureza programática, em sua grande maioria. Nesse sentido, a plena eficácia dessas normas estaria condicionada ao desenvolvimento de políticas públicas e a elaboração normativa que lhe atribua efeitos concretos.

Nesse contexto, como forma de garantir o exercício do direito à saúde, deve Estado, no desempenho de seu papel de poder-dever de larga intervenção no âmbito social, valer-se de políticas públicas sociais e econômicas para efetivar tal direito expressamente previsto no plano constituinte. Entende-se por políticas públicas os mecanismos criados pelo governo e a sociedade civil no sentido de transformar seus propósitos em programas, projetos e ações. As ações de políticas públicas implicam em “diretrizes, estratégias, prioridades e ações que constituem as metas perseguidas pelos órgãos públicos, em resposta às demandas políticas, sociais e econômicas e para atender aos anseios oriundos das coletividades" ${ }^{\prime 2}$.

Ocorre que as inúmeras demandas sociais envolvendo os direitos sociais, especialmente o direito à saúde, resultaram numa ineficiência do Poder Executivo no que tange à administração de recursos e o Poder Legislativo no que diz respeito à elaboração de legislações que garantam a efetividade desses direitos. Assim, como forma de garantir a concretude de seus direitos, a coletividade vem se utilizando das vias jurisdicionais, ensejando a judicialização das políticas públicas, especialmente a judicialização do direito fundamenta à saúde.

\section{JudicializaÇão de Políticas PÚBlicas NA SEARA dA SAÚdE}

A judicialização das políticas públicas desenvolveu-se principalmente na esfera dos serviços de saúde. Tal fato se justifica porque, as dimensões constitucionais e infraconstitucionais acerca desse direito, somadas ao contexto da realidade precária da saúde brasileira, coube ao Judiciário definir os parâmetros da prestação de tais serviços públicos. Observa-se o fenômeno da judicialização da política quando o Judiciário, no desemprenho normal de suas funções, tem sua atuação afetada de modo significativo devido as condições de caráter político. Reside, pois, em questões relevantes de cunho político, moral e social que são objetos de apreciação judicial em caráter final.

Trata-se daquelas atividades tipicamente preponderantes dos Poderes Legislativo e Executivo que são transferidas ao Poder Judiciário, haja vista as reiteradas condutas omissivas das respectivas esferas estatais em implementar o direito à saúde nos moldes propostos pelo texto constitucional. Com isso, os tribunais e magistrados acabam por se tornarem atores políticos, conquanto com singularidades e embasamentos distintos dos demais poderes. Eles se tornam personagens centrais na resolução de relevantes conflitos morais e políticos, cujos efeitos de suas decisões acabam por impactar no sistema político. Nesse sentido, atualmente o Judiciário exerce importante papel na concretização dos direitos fundamentais aos cidadãos, uma vez que suas decisões constituem verdadeiros mecanismos de poder e, direta ou indiretamente, participam e influenciam a formação da vontade política predominante.

Há uma conversão de circunstâncias tradicionalmente consideradas de natureza política em situações jurídicas, o que enseja a origem da jurisdicionalização do processo decisório, aumentando a tensão entre política e o direito.

40 CANOTILHO, Joaquim José Gomes. Direito Constitucional e Teoria da Constituição. 7. ed. Coimbra: Almedina, 2003.

41 SARMENTO, Daniel. Direitos fundamentais e relaçoes privadas. 2. ed. Rio de Janeiro: Lumem Juris, 2008.

42 CARVAlho FILHO, José dos Santos. Políticas públicas e pretensões judiciais determinativas: IN: FORTINI, Cristiana; ESTEVES, Júlio C. Santos; DIAS, Maria Tereza Fonseca (Org.). Políticas públicas: possibilidades e limites. Belo Horizonte: Fórum, 2008. p. 110-111. 
Com o advento da constituição democrática, o Judiciário assumiu o papel de garantir o exercício, implementação e concretização de direitos fundamentais coletivos e individuais expressamente previstos no plano constituinte, sempre que verificada a omissão do executivo e legislativo.

Nesse contexto, se antes o Poder Judiciário brasileiro exercia papel coadjuvante, devido aos imensos números de processos e a não positivação de direitos por parte do Poder Legislativo e a ineficácia do Poder Executivo em efetivar essas políticas públicas, ele passou a ser protagonista, especialmente na área da saúde.

Nesse contexto, o direito fundamental à saúde deve ser interpretado extensivamente, de modo a garantir democraticamente a ampla proteção da pessoa humana. Joaquim Carlos Salgado "refere-se ao princípio da maior extensabilidade como aquele que confere ao direito fundamental uma interpretação ampla, dada a alta carga valorativa que possuem. Os direitos fundamentais não podem ser restringidos, devendo o intérprete aplica-los da forma mais abrangente possível ${ }^{43 \prime \prime}$.

Esse cenário procede do alto volume de processos judiciais a tratar da saúde pública e suplementar e do biodireito. Segundo o Ministério da Saúde ${ }^{44}$, em 2005, a União gastou diretamente R \$2,5 milhões com aquisição de medicamentos solicitados pela via judicial e foi citada como ré em 387 processos, fato esse que evidencia claramente a omissão do Estado em implementar política pública de saúde, tal como previsto no plano constitucional. Em 2007, o gasto passou para R 15 milhões destinados ao atendimento de aproximadamente três mil ações. Em 2008, as despesas alcançaram R \$ 52 milhões.

Esses números refletem os gastos gerados e a implicação das decisões judiciais no cenário político e econômico do país. Consoante um estudo feito sobre a judicialização, é possível detectar algumas características comuns nos processos nas diversas regiões do país. Primeiro, a maioria dos pedidos constitui-se em demanda individual e os deferimentos das ações baseiam-se unicamente na prescrição medicamentosa apresentada pelo reivindicante. Já a segunda característica remete-se ao fato de a prescrição conter medicamentos incorporados ou não pela assistência farmacêutica do SUS, alguns sem registro no país ou em indicação terapêutica não constante no registro sanitário. E, a terceira, pauta-se no crescimento exponencial das demandas judiciais e dos gastos com medicamentos ${ }^{45}$.

A Administração Pública afirma não ser possível cumprir todas as ordens judiciais e como mecanismo de defesa contra argumentativa baseia-se dogmaticamente na teoria da reserva do possível. Segundo esse princípio, "todo orçamento possui um limite que deve ser utilizado de acordo com exigências de harmonização geral”46. Para a teoria da reserva do possível, os recursos não serão disponíveis diante das necessidades quase sempre infinitas a serem por eles supridas, de forma que deve haver limites para implementação efetiva dos direitos sociais prestacionais. Explica Barcelos que:

A expressão reserva do possível procura identificar o fenômeno econômico da limitação dos recursos disponíveis diante das necessidades quase sempre infinitas a serem por eles supridas. Esta teoria claramente postula que há limites de possibilidades matérias aos direitos sociais prestacionais, independente de eles estarem legalmente previstos ou não. Assim, de nada adiantaria a previsão constitucional se não existirem recursos disponíveis para custeio destas prestações. E é justamente nas situações em que o Estado não contempla estes direitos que os cidadãos buscam em vias judiciais a efetivação ${ }^{47}$

43 MOREIRA, Bárbara Antonina E. de Campos; FERNANDES, Bianca de Menezes; RIBEIRO, Brenda Senna Guimarães. O direito à saúde sob a ótica da hermenêutica dos direitos fundamentais. In: DAMASCENO, Maria Helena; MEGALE, Silva (Org.). Horizontes Hermenêuticos. Belo Horizonte: Imprensa Universitária da UFMG, 2012. p. 131.

44 BRASIL. Ministério da Saúde. Ações judiciais comprometem política de saúde. Brasília, 2008. Disponível em: <http://www.sinmedmg.org.br/visualizacao-de-noticias/ler/7032/acoes-judiciais-comprometem-politica-de-saude>. Acesso em: 10 set. 2017.

45 PEPE, Vera Lúcia Edais et al. A judicialização da saúde e os novos desafios da gestão da assistência farmacêutica. Revista Ciência e Saúde Coletiva, v. 5, n. 15, p. 2405-2414, abr. 2010. Disponível em: < http://www.scielo.br/pdf/csc/v15n5/v15n5a15>. Acesso em: 10 set. 2017.

46 NUNES, José Avelãs; SCARFF, Fernando Facury. Os tribunais e o direito à saúde. Porto Alegre: Livraria do Advogado, 2011.

47 BARCELLOS, Ana Paula de. A eficácia jurídica dos princípios constitucionais: o princípio da dignidade da pessoa humana. 3. ed. Rio de Janeiro: Renovar, 2011. p. 236. 
Segundo essa concepção, não há recursos disponíveis para custeio destas prestações de modo que não se pode exigir uma atuação estatal. E, baseando nisso, o Poder Executivo tem invocado a falta de recursos públicos para atender as pretensões judiciais por meio da Teoria da Reserva do Possível e da prerrogativa da Administração basear-se nos mecanismos de conveniência e oportunidade para concretizar determinas políticas. Tal premissa teórica contraria a ordem constitucional democrática, haja vista que se trata de argumento utilizado para justificar dogmaticamente a interpretação restritiva do direito fundamental à saúde baseado em razões econômico-capitalista de finitude dos recursos públicos.

Como reflexo disso, a população recorre às vias judiciais para efetivação de seus direitos, pautando-se na essencialidade desse direito fundamental e também na teoria do mínimo existencial. Esse, por sua vez, corresponde às condições elementares de direitos sociais que, quando obtidos determinados grau de realização, constituem uma garantia institucional e um direito subjetivo, Logo, restringe-se a possibilidade de reversão, conduzindo ao princípio da vedação ao retrocesso social, tutelando-se a dignidade da pessoa humana.

Nessa perspectiva, o Judiciário, diante de uma demanda, deve determinar que seja salvaguardado o mínimo existencial antes de analisar quaisquer outros aspetos de ordem orçamentaria e política. Para tanto, deve-se observar a existência dos subsídios: saúde pública básica, educação, assistência aos necessitados e o acesso à justiça, elementos estes que devem ser concretizados e exigíveis perante o Judiciário em caso de omissão pelos órgãos competentes.

A premissa teórica do mínimo existencial compatibiliza-se com a interpretação sistemático-integrativo-democrático do direito fundamental à saúde, haja vista que resguarda seu exercício tanto na esfera individual quanto coletiva. Em contrapartida, verifica-se que a proposição jurídica da reserva do possível não se compatibiliza com a constitucionalidade democratizante dos direitos fundamentais, especialmente o direito à saúde, haja vista que tal argumento é frequentemente utilizado pelo Judiciário como justificativa para limitar, restringir ou suprimir o exercício individual ou coletivo do direito à saúde, baseando-se em razões econômicas de finitude dos recursos públicos.

\section{Os efeitos da Judicialização da saúde e a atuação do Supremo Tribunal Federal}

O objetivo do presente item do artigo cientifico é investigar e debater os argumentos e fundamentos hermenêuticos utilizados pelo Supremo Tribunal Federal no que tange à análise das pretensões que buscam proteger o exercício do direito à saúde, especificamente no que atine ao fornecimento estatal de medicamentos de alto custo.

Pretende-se identificar aporias nas proposições hermenêuticas utilizadas pelo Supremo Tribunal Federal, de modo a evidenciar as limitações da pesquisa e, assim, sugerir novos questionamentos que orientarão investigações científicas futuras. Ressalta-se, ainda, que a originalidade da abordagem proposta justifica-se na desconstrução das premissas hermenêuticas utilizadas pelo Supremo Tribunal Federal, evidenciando sua incompatibilidade com a interpretação sistemático-integrativa e extensivo-democrática do direito fundamental à saúde expressamente previsto no plano constituinte como um direito de dimensão coletiva e individual.

\subsection{Os julgados do Supremo Tribunal Federal e a fixação de parâmetros como norteador de decisões judiciais}

O Estado Democrático de Direito funda-se na premissa da efetivação dos direitos fundamentais como corolário da dignidade da pessoa humana. A constituição brasileira vigente possui núcleo normativo de cunho axiológico, ressaltando-se que tal argumento deve ser o fundamento regente para a interpretação extensiva da saúde enquanto direito fundamental. Ao Judiciário caberá o papel de interpretar democraticamen- 
te o respectivo direito, garantindo-se seu exercício a todos indistintamente, não podendo, jamais, se utilizar de critérios interpretativos voltados a restringir ou suprimir o exercício de qualquer direito fundamental, especialmente o direito à saúde. Nesse sentido, Eduardo Ribeiro Moreira afirma que

A judicialização da política ganha limites ao lado de um aumento de força, pois não é qualquer política pública, mas aquela com base em metas previstas na Constituição. Para tanto os direitos fundamentais são eregidos a fundamentos do controle, corrigindo as impropriedades das políticas públicas em julgamento conduzidos pelos direitos fundamentais como vetores. Isso fica mais bem contextualizado à visão de que o Poder Judiciário é, também ele, o condutor da democracia ${ }^{48}$.

A inércia governamental no tocante à implementação de políticas públicas voltada à área da saúde é bem antiga. Em uma retrospectiva na jurisprudência do STF no tocante à concessão de medicamentos, observa-se ações proativas do Tribunal em criar mecanismos para garantir esse direito. No AI 238328 AgR / RS, j. em 16/11/199949, rel. Ministro Marco Aurélio, o STF adotou a política de concessão de medicamentos: “a Constituição Federal assegura aos necessitados o fornecimento, pelo Estado, dos medicamentos indispensáveis ao restabelecimento da saúde, especialmente quando em jogo doença contagiosa como é a Síndrome da Imunodeficiência Adquirida". Observa-se que já no ano de 1999 a questão da judicialização da saúde já era tema em pauta no Supremo Tribunal, ressaltando-se que o posicionamento adotado à época era voltado à interpretação extensiva do direito fundamental à saúde, considerando-se que a escassez e limitação de recursos públicos não fica em evidência nos julgados supramencionados.

Também no RE 195192/RS ${ }^{50}$, em 22/02/2000, rel Marco Aurélio salienta acerca da responsabilidade linear dos entes federados na concessão de medicamentos raros. Também nos julgado RE $255627^{51} \mathrm{AgR} /$ RS, j. 21/11/2000, rel. Min. Nelson Jobim e AI 486816 AgR / RJ , j. 12/04/2005, relator Carlos Velloso, imputa-se a responsabilidade do Estado quanto à concessão. O bloqueio de verbas públicas como medida coercitiva para garantia do direito à saúde tornou-se rotineira (AI 59718252 AgR / RS, j. em 10/10/2006, Min. Cézar Peluso). Na ADPF n. $45^{53}$ (BRASIL, 2004), o STF analisa a tensão entre os princípios da reserva do possível e o mínimo existencial, afirmando, em suma, que as questões orçamentárias, a título de cláusula de reserva do possível, somente configurariam óbice à implementação do direito à saúde se a insuficiência de recursos fosse objetiva e concretamente demonstrada.

A partir do ano 2000 começa a ganhar força no Supremo Tribunal Federal os princípios da reserva do possível como fundamento utilizado para restringir o acesso à saúde. Corroborando com essa tese, Ana Paula de Barcellos afirma

As políticas públicas são indispensáveis para a garantia e a promoção dos direitos fundamentais - o fato é que toda e qualquer ação estatal envolve gasto de dinheiro público e os recursos públicos são limitados. Essas são evidências fáticas e não teses jurídicas. [...] As políticas públicas, igualmente, envolvem gastos. E

48 MOREIRA, Eduardo Ribeiro. A possibilidade de controle judicial das políticas públicas. In: FIGUEIREDO, Marcelo. (Coord.). Novos Rumos para o Direito Público - Reflexões em Homenagem à professora Lúcia Valle Figueiredo. Belo Horizonte: Fórum, 2012. p. 162.

49 BRASIL. Supremo Tribunal Federal. Agravo Regimental no agravo de instrumento AI 238328 AgR /RS. Relator: Ministro Marco Aurélio. Diário de Justiça Eletrônico, 16 de novembro de 1999. Disponível em: < http://redir.stf.jus.br/paginadorpub/paginador.jsp?docTP=AC\&docID=291210>. Acesso em: 20 set. 2017.

50 BRASIL. Supremo Tribunal Federal. Recurso Extraordinário n. 195192/RS. Relator: Marco Aurélio. Diário de Justiça Eletrônico, 31 de mar. 2000. Disponível em: < http://redir.stf.jus.br/paginadorpub/paginador.jsp?docTP=AC\&docID=234359.Acesso em: 20 set. 2017.

51 BRASIL. Supremo TribunalFederal. Recurso Extraordinário 255627 AgR / RS. Relator Min. Nelson Jobim Diário de Justica Eletrônico, 21 de novembro de 2000. Disponível em: < http://redir.stf.jus.br/paginadorpub/paginador.jsp?docTP=AC\&docID=365054>. Acesso em: 20 set. 2017.

52 BRASIL. Supremo Tribunal Federal. Agravo Regimental no agravo de instrumento AI 597182 AgR / RS. Relator Min. Cézar Peluso. Diário de Justiça Eletrônico 10 de outubro de 2006, Disponível em: < http://redir.stf.jus.br/paginadorpub/paginador. jsp?docTP=AC\&docID=390282>. Acesso em: 20 set. 2017.

53 BRASIL. Supremo Tribunal Federal. ADPF n. 45 (BRASIL, 2004) Diário de Justiça Eletrônico Disponível em: http://www.sbdp. org.br/arquivos/material/343_204\%20ADPF\%202045.pdf . Acesso em: 20 set. 2017. 
como não há recursos ilimitados, será preciso priorizar e escolher em que o dinheiro público disponível será investido ${ }^{54}$.

O entendimento da autora mencionada acima ilustra o posicionamento do Supremo Tribunal Federal quanto ao tema judicialização do direito fundamental à saúde. O Ministro Relator da ADPF n. 45, Celso de Mello, é categórico ao afirmar que "a questão da legitimidade constitucional do controle e da intervenção do Poder Judiciário em tema de implementação de políticas públicas, quando configurada hipótese de abusividade governamental" ${ }^{55}$. Nesse contexto, abusividade governamental pode ser entendida como omissão estatal quanto à garantia efetiva do direito à saúde ou se deve entender que tal abusividade decorre apenas da conduta comissiva praticada pelo Estado? Mesmo considerando que a saúde é um direito fundamental corolário da dignidade humana, de interpretação extensivo-democrática, verifica-se no entendimento preconizado pelo Supremo Tribunal que a legitimidade do judiciário intervir no tema decorre da comprovação em juízo de negativa do Estado em assegurar o exercício do direito à saúde.

A indagação racional (aporia) que surge nesse contexto é a seguinte: estaria o Supremo Tribunal Federal utilizando-se de parâmetro hermenêutico de interpretação restritiva do direito fundamental à saúde baseado em critérios metajurídicos (econômicos e escassez de recursos)?

Verifica-se nesse entendimento adotado pelo Supremo Tribunal Federal a adoção de argumentos econômicos e orçamentários como justificativa da interpretação restritiva do direito fundamental à saúde. Trata-se de postura que não condiz com a constitucionalidade democrática dos direitos fundamentais, que preconiza pelo exercício extensivo de tais direitos como forma de garantir a inclusão e proteção integral da pessoa humana.

Ressalta-se que o texto constitucional, visto sob a ótica das proposições hermenêutico-democratizantes, não pode ser interpretado de modo a limitar ou suprimir o exercício igual de direitos fundamentais pelos cidadãos. Admitir esse tipo de interpretação é reconhecer o protagonismo judicial como lócus de violação dos direitos fundamentais previstos no plano constituinte. Lênio Luiz Streck elucida a questão em debate ao afirmar que "a crítica à discricionariedade judicial não é uma proibição de interpretar" "56. A interpretação visa dar sentido à norma jurídica diante das peculiaridades do caso concreto, ressaltando-se que o "direito é composto por regras e princípios comandados pela Constituição" ${ }^{57}$. Os julgadores não podem ser valer de qualquer critério hermenêutico para interpretar o texto da constituição brasileira vigente, pois "o drama da discricionariedade que critico reside no fato de que esta transforma os juízes em legisladores" ${ }^{\text {, }}$, propiciando "a criação do próprio objeto do conhecimento, típica manifestação do positivismo" 59 . A racionalidade do julgador (ministros do Supremo Tribunal Federal) "não pode ser a fonte iluminadora do significado de tudo o que pode ser enunciado sobre a realidade" ${ }^{\prime 0}$.

Note-se que a preocupação inicial do Tribunal pautava-se em resguardar os preceitos constitucionais e não o problema orçamentário. Contudo, o efeito multiplicador dessas ações acabou por impactar nas decisões do STF, que até então adotava a política de concessão de medicamentos na grande maioria dos casos. No julgado, Suspensão de Tutela Antecipada n. 91/AL ${ }^{61}$, nota-se essa modificação, uma vez que o STF entendeu que o Estado do Alagoas não poderia ser obrigado a fornecer medicamento que não se encontrava

54 BARCELLOS, Ana Paula de. Constitucionalização das políticas públicas em matéria de direitos fundamentais: o controle politico social e o controle jurídico no espaço democrático. Revista de Direito do Estado-RDE, n. 3, p. 17-54, jul./set. 2006.

55 MOREIRA, Eduardo Ribeiro. A possibilidade de controle judicial das políticas públicas. In: FIGUEIREDO, Marcelo. (Coord.). Novos Rumos para o Direito Público - Reflexões em Homenagem à professora Lúcia Valle Figueiredo. Belo Horizonte: Fórum, 2012. p. 172.

56 STRECK, Lenio Luiz. O que é isto: decido conforme minha consciência? Porto Alegre: Livraria do Advogado, 2012. p. 93.

57 STRECK, Lenio Luiz. O que é isto: decido conforme minha consciência? Porto Alegre: Livraria do Advogado, 2012. p. 93.

58 STRECK, Lenio Luiz. O que é isto: decido conforme minha consciência? Porto Alegre: Livraria do Advogado, 2012. p. 93.

59 STRECK, Lenio Luiz. O que é isto: decido conforme minha consciência? Porto Alegre: Livraria do Advogado, 2012. p. 93.

60 STRECK, Lenio Luiz. O que é isto: decido conforme minha consciência? Porto Alegre: Livraria do Advogado, 2012. p. 93-94.

61 BRASIL. Supremo Tribunal Federal. Suspensão da Tutela Antecipada STA 91/AL. Disponível em: < https://stf.jusbrasil.com.br/ jurisprudencia/19139898/suspensao-de-tutela-antecipada-sta-91-al-stf>. Acesso em: 24 set. 2017. 
na lista do SUS, apesar de ele se encontrar registrado pela Agência Nacional de Vigilância Sanitária (ANVISA). A partir desse julgamento verifica-se o posicionamento hermenêutico do Supremo Tribunal Federal em se utilizar de argumentos econômicos e limitação orçamentária justamente para limitar o exercício e a efetivação do direito fundamental à saúde.

O solipsismo dos ministros do Supremo Tribunal Federal fica evidente no julgamento da demanda acima mencionada, já que criam livremente interpretações e entendimentos para afastar a responsabilidade do estado em garantir o direito à saúde. O problema da discricionariedade judicial tem sua origem bem definida em Kelsen e Hart, já que tinha "o objetivo, ao mesmo tempo, de resolver um problema considerado insolúvel, representado pela razão prática eivada de solipsismo [...], e de reafirmar o modelo de regras do positivismo, no interior do qual os princípios (gerais do direito) - equiparados a valores - mostravam-se como instrumentos para a confirmação desse fechamento" ${ }^{\prime 2}$.

O STF promoveu a audiência pública de $\mathrm{n}^{\circ} 04^{63} \mathrm{sob}$ a argumentação de elaborar mecanismos e critérios para servirem de paradigmas às decisões judiciais brasileiras, sob o pretexto de evitar decisões subjetivas e garantir segurança jurídica. A audiência ocorreu nos meses de abril e maio de 2009. Os principais pontos discutidos nela foram: a) responsabilidade dos entes da federação em matéria de direito à saúde; b) Obrigação do Estado de fornecer prestação de saúde prescrita por médico não pertencente ao quadro do SUS ou sem que o pedido tenha sido feito previamente à Administração Pública; c) Obrigação do Estado de custear prestações de saúde não abrangidas pelas políticas públicas existentes; d) Obrigação do Estado de disponibilizar medicamentos ou tratamentos experimentais não registrados na ANVISA ou não aconselhados pelos Protocolos Clínicos do SUS; e) Obrigação do Estado de fornecer medicamento não licitado e não previsto nas listas do SUS; f) Fraudes ao Sistema Único de Saúde.

$\mathrm{Na}$ audiência discutiu-se a necessidade de transferência de atribuições aos municípios de obrigações frente ao direito à saúde que originalmente pertenciam aos Estados e a União, o que para o Ministro Gilmar Mendes, anseia por uma reavaliação institucional destes.

Como reflexos das discussões na audiência Pública, no julgado AIAr n. 553.712/RS ${ }^{64}$, o relator, Ministro Ricardo Lewandowski ressaltou o entendimento da Corte, exarado em julgados já mencionados, no sentido de que o Poder Público, independentemente do ente federativo brasileiro, não pode mostrar-se indiferente aos problemas da saúde no Brasil. Nesse julgado ratificou-se o entendimento de que todos os entes federativos são destinatários diretos da regra contido no art. 195 da CR/88.

Importante ressaltar que as audiências públicas realizadas não asseguram a democraticidade do provimento jurisdicional, haja vista que se trata de técnica processual utilizada para demonstrar apenas formalmente a participação popular no debate do tema judicialização do direito à saúde. O apontamento crítico que ora se apresenta justifica-se, inicialmente, no fato de que não foi assegurado amplamente a participação popular nas respectivas audiências, uma vez que não se verifica um debate em que todos os interessados pudessem debater a formação do mérito processual. Além disso, os pontos controversos debatidos não foram racionalmente enfrentados pelos julgadores no ato de decidir, considerando-se que foi um meio de ratificar entendimento anteriormente sedimentado pelo Supremo Tribunal. Dessa forma, fica evidente a impossibilidade objetiva de obter uma resposta do órgão julgador que coincida com as diretrizes propostas pela hermenêutica constitucional que preza pela interpretação extensiva e democrática dos direitos fundamentais como forma de assegurar a inclusão e proteção integral das pessoas.

62 STRECK, Lenio Luiz. O que é isto: decido conforme minha consciência? Porto Alegre: Livraria do Advogado, 2012. p. 97.

63 MACHADO, Tereza Robichez de Carvalho. Judicialização da saúde: analisando a audiência pública no Supremo Tribunal Federal. Revista de Bioética, p. 561-568, 2014. Disponível em: <http://www.scielo.br/pdf/bioet/v22n3/v22n3a20.pdf>. Acesso em: 24 set. 2017.

64 BRASIL. Supremo Tribunal Federal. Agravo Regimental no agravo de instrumento. n. 553.712/RS, relator, Ministro Ricardo Lewandowski, Diário de Justiça Eletrônico, 19 de maio de 2009. Disponível em: http://redir.stf.jus.br/paginadorpub/paginador. jsp?docTP $=$ AC\&docID=595522Acesso em: 20 set. 2017. 
No caso de medicamentos de alto custo, em 17 de março de 2010, o Plenário do Supremo Tribunal Federal, julgou as Suspensões de Tutela (STA) ns. 175, 211 e 278, as Suspensões de Segurança n. ${ }^{\circ}$ 3724, 2944, 2361, 3345 e 3355 e da Suspensão de Liminar (SL) n. 47, de relatoria do Ministro Gilmar Mendes. Essas ações foram interpostas pela Administração Pública em virtude de sua condenação em decisões judiciais que determinaram ao Sistema Único de Saúde (SUS) o fornecimento de medicamentos de alto custo e tratamentos não oferecidos pelo sistema a pacientes de doenças graves ${ }^{65}$.

Em sua relatoria, o Ministro Gilmar Mendes assinalou a necessidade de se redimensionar a questão da judicialização do direito à saúde no Brasil, apresentando alguns parâmetros a serem analisados no caso concreto. Esclareceu a necessidade de se avaliar as especificidades do caso e todos elementos normativos e fáticos da questão jurídica debatida, analisando a existência ou não de uma política estatal que abranja a prestação de saúde pleiteada pela parte ${ }^{66}$.

Segundo o relator, se a prestação de saúde pleiteada não estiver entre as políticas do Sistema Único de Saúde (SUS), "é imprescindível distinguir se a não prestação decorre de (1) uma omissão legislativa ou administrativa, (2) de uma decisão administrativa de não fornecê-la ou (3) de uma vedação legal de sua dispensação". No caso de condenação do Estado ao fornecimento de medicamento não registrado na Agência Nacional de Vigilância Sanitária (ANVISA), o que é vedado pelo art. 12 da Lei n. 6.360/1976 e coloca em risco a saúde pública, entende o relator que não deve ser concedido ${ }^{67}$.

Assinala ainda Gilmar Mendes que outro ponto a ser analisado é a existência de motivação para o não fornecimento de determinado remédio ou tratamento pelo Sistema Único de Saúde (SUS). Nessa hipótese, podem ocorrer duas situações: “ $1^{\circ}$ ) o SUS fornece tratamento alternativo, mas não adequado a determinado paciente; $2^{\circ}$ ) o SUS não tem tratamento específico para determinada patologia." Na visão do Ministro, se o SUS fornece tratamento semelhante, não pode o paciente pleitear tratamento diverso e ainda com ônus maior para o Estado, devendo ser ele o tratamento oferecido. Agora, se esse tratamento, em razão específica do organismo do paciente demonstrar-se ineficaz mediante prova cabal, poderá ter o pleito atendido ${ }^{68}$.

Ponderou ainda Gilmar Mendes acerca da necessidade de revisão periódica dos protocolos existentes e de elaboração de novos protocolos. No tocante aos novos tratamentos que ainda não foram incorporados pelo SUS, deve-se verificar se não se trata de tratamentos experimentais, os quais o Estado não deve conceder em seu entender. No que diz respeito à omissão administrativa no tratamento de determinada patologia, entende o Ministro que essa hipótese poderá ser objeto de impugnação judicial, tanto por ações individuais como coletivas. Afirmou, também, que a responsabilidade dos entes da federação é solidária ${ }^{69}$.

Em síntese, observa-se que, no âmbito da STA $175^{70}$, o Ministro Gilmar Mendes aduziu que impor ao Estado o financiamento de todas as prestações na área da saúde acarretaria problemas no comprometimen-

65 BRASIL. Supremo Tribunal Federal. Poder Público deve custear medicamentos e tratamentos de alto custo a portadores de doenças graves, decide o Plenário do STF. Disponível em: <http://www.stf.jus.br/portal/cms/verNoticiaDetalhe.asp?idConteudo=122125>. Acesso em 24 set. 2017.

66 BRASIL. Supremo Tribunal Federal. Poder Público deve custear medicamentos e tratamentos de alto custo a portadores de doenças graves, decide o Plenário do STF. Disponível em: <http://www.stf.jus.br/portal/cms/verNoticiaDetalhe.asp?idConteudo=122125>. Acesso em 24 set. 2017.

67 BRASIL. Supremo Tribunal Federal. Poder Público deve custear medicamentos e tratamentos de alto custo a portadores de doenças graves, decide o Plenário do STF. Disponível em: <http://www.stf.jus.br/portal/cms/verNoticiaDetalhe.asp?idConteudo=122125>. Acesso em 24 set. 2017.

68 BRASIL. Supremo Tribunal Federal. Poder Público deve custear medicamentos e tratamentos de alto custo a portadores de doenças graves, decide o Plenário do STF. Disponível em: < http://www.stf.jus.br/portal/cms/verNoticiaDetalhe.asp?idConteudo=122125>. Acesso em 24 set. 2017.

69 BRASIL. Supremo Tribunal Federal. Poder Público deve custear medicamentos e tratamentos de alto custo a portadores de doenças graves, decide o Plenário do STF. Disponível em: <http://www.stf.jus.br/portal/cms/verNoticiaDetalhe.asp?idConteudo=122125>. Acesso em 24 set. 2017.

70 BRASIL. Supremo Tribunal Federal. Agravo Regimental, Suspenção de tutela antecipada 175/CE. Relator: Gilmar Mendes. Diário de Justiça Eletrônico, 24 jun. 2009. Disponível em: <http://www.stf.jus.br/arquivo/cms/noticianoticiastf/anexo/sta175.pdf>. Acesso em:10 set. 2017. 
to do SUS como um todo. Isso prejudicaria, de maneira geral, o atendimento, o tratamento da população que possui mais necessidades. Enunciou ainda que, nesses termos, deverá ter preferência o tratamento disponibilizado pelo SUS em detrimento do escolhido pelo usuário, porém em ocorrência da ineficácia da política pública de saúde deverão ser levados à revisão periódica dos protocolos existentes e à formulação de novos para a devida prestação ${ }^{71}$.

Novamente no julgamento do caso referente aos medicamentos de alto custo prevaleceu o protagonismo judicial dos ministros do Supremo Tribunal Federal, tendo em vista que outros argumentos racionais sequer foram apresentados e debatidos judicialmente. $O$ debate do mérito processual concentrou-se na autoridade dos julgadores, que fundados em juízos apriorísticos, de uma hermenêutica que privilegia a interpretação unilateral do julgador, mantiveram o entendimento de que deve prevalecer a premissa da escassez dos recursos públicos como justificativa para limitar o acesso ao direito à saúde.

Os destinatários do provimento final foram excluídos do debate processual, contrariando a proposição teórica de que a democraticidade do conteúdo de mérito de uma ação coletiva deve assegurar que todos os sujeitos afetados pelos efeitos jurídicos da decisão sejam seus coautores. Para Vicente de Paula Maciel Júnior, a ações coletivas como ações temáticas permitem "a participação dos legitimados na formação do provimento, resgatando às partes (interessados difusos), o direito de participação em contraditório no processo decisório que os afetará”’2.

Também nos julgados RE $566.471^{73}$ e RE $657.718^{74}$, de relatoria do Ministro Marco Aurélio, ainda não julgados, os Ministros Marco Aurélio, Luis Roberto Barroso e Edson Fachin também tentaram esmiuçar alguns parâmetros para veicular as decisões judiciais. Ressalta-se que no RE 566.471, Marco Aurélio sustentou que o reconhecimento do direito individual ao fornecimento de medicamento de alto custo não incluso em Política Nacional de Medicamentos ou em Programa de Medicamentos de Dispensação em Caráter Excepcional por parte da Administração Pública, tem como condicionante a comprovação da imprescindibilidade, ou seja, adequação e necessidade, e da impossibilidade de substituição do medicamento por outro já constante na lista do SUS, e também da incapacidade financeira do paciente ou membros de sua família ${ }^{75}$.

Compreende o relator que, no caso de direitos sociais fundamentais como a saúde, verificada a transgressão do mínimo existencial, deve-se reconhecer a validade da atuação de juízes e tribunais em situações concretas que não foram objeto de políticas públicas. Se satisfeitos os dois critérios da imprescindibilidade do medicamento e da falta de espontaneidade dos membros da família solidária do paciente em custear o medicamento, deve ser concedido independentemente do valor.

O posicionamento acima mencionado compatibiliza-se com a interpretação sistemática e inclusiva do direito fundamental à saúde, destacando-se novamente que argumentos de cunho meramente econômico e orçamentário não podem ser vistos como razões a justificar a não implementação do direito fundamental à saúde no que atine aos medicamentos de alto custo. Porém, verifica-se que o julgador cria unilateralmente novos critérios hermenêuticos para a análise do tema, excluindo-se todos os destinatários do provimento do debate jurídico e racional dos pontos controversos que integram o mérito processual, ratificando entendimento anteriormente sedimentado que privilegia o protagonismo judicial.

71 BRASIL. Supremo Tribunal Federal. Poder Público deve custear medicamentos e tratamentos de alto custo a portadores de doenças graves, decide o Plenário do STF. Disponível em: <http://www.stf.jus.br/portal/cms/verNoticiaDetalhe.asp?idConteudo=122125>. Acesso em 24 set. 2017.

72 MACIEL JUNIOR, Vicente de Paula. Teoria das Ações Coletivas: as ações coletivas como ações temáticas. São Paulo: Ltr, 2006. p. 185.

73 BRASIL. Supremo Tribunal Federal. RE 566.471. Disponível em <http://redir.stf.jus.br/paginadorpub/paginador. jsp?docTP=TP\&docID=12071365> . Acesso em: 24 set. 2017.

74 BRASIL. Supremo Tribunal Federal. RE 657.718. Disponível em <http://www.stf.jus.br/arquivo/cms/noticiaNoticiaStf/anexo/RE657718.pdf>. Acesso em 24 set. 2017.

75 BRASIL. Supremo Tribunal Federal. Pedido de vista adia julgamento sobre acesso a medicamentos de alto custo por via judicial. Disponível em: <http://www.stf.jus.br/portal/cms/verNoticiaDetalhe.asp?idConteudo=326275>. Acesso em: 24 set. 2017. 
Em que pese o dever no Estado em conceder medicamentos e do dever de solidariedade da família, sabe-se que a análise financeira deve-se pautar nas condições do paciente e não de sua família, evitando-se uma ingerência do Estado na esfera privada. Tais critérios solitariamente criados pelos ministros do STF são utilizados para limitar e obstaculizar o acesso à saúde daquelas pessoas que necessitam de medicamentos de alto custo, confirmando entendimento anteriormente mencionado, qual seja, o solipsismo judicial como óbice a qualquer participação dos interessados na construção do mérito processual.

O ministro Barroso reproduz e adota o posicionamento atual dos demais ministros do Supremo Tribunal Federal, que se utilizam de diversas condições para obstaculizar o acesso do paciente a medicamentos de alto custo. Em seu voto-vista, Barroso pondera que:

O Estado não pode ser obrigado por decisão judicial a fornecer medicamento não incorporado pelo SUS, independentemente de custo, salvo hipóteses excepcionais, em que preenchidos cinco requisitos: (i) a incapacidade financeira de arcar com o custo correspondente; (ii) a demonstração de que a não incorporação do medicamento não resultou de decisão expressa dos órgãos competentes; (iii) a inexistência de substituto terapêutico incorporado pelo SUS; (iv) a comprovação de eficácia do medicamento pleiteado à luz da medicina baseada em evidências; e (v) a propositura da demanda necessariamente em face da União, que é a entidade estatal competente para a incorporação de novos medicamentos ao sistema. Ademais, deve-se observar um parâmetro procedimental: a realização de diálogo interinstitucional entre o Poder Judiciário e entes ou pessoas com expertise técnica na área da saúde tanto para aferir a presença dos requisitos de dispensação do medicamento, quanto, no caso de deferimento judicial do fármaco, para determinar que os órgãos competentes avaliem a possibilidade de sua incorporação no âmbito do SUS ${ }^{76}$.

A análise de Barroso estabelece parâmetros no sentido de condensar ações judiciais advindas de direitos sociais não prestados pelo Estado. Se o medicamento consta na lista do SUS e se comprovada sua necessidade e incapacidade financeira do paciente, existe a obrigação do Estado em concedê-lo. Agora, se não foi o fármaco incorporado pelo SUS, não cabe ao Estado o fornecimento.

O ministro Barroso coloca-se como protagonista do debate processual e, fundado nas convicções de uma hermenêutica solitária e metajurídica, cria critérios para limitar o acesso aos medicamentos de alto custo e ignora qualquer tipo de participação dos interessados no provimento quanto ao debate do mérito. Utiliza-se o ministro de sua sabedoria inato-oracular para definir os critérios por ele considerados relevantes para definir a vida de inúmeros cidadãos brasileiros, sem permitir, sequer, qualquer diálogo com os sujeitos afetados diretamente por sua decisão.

$\mathrm{Na}$ visão de Fachin essas ações deveriam ser de natureza coletiva, sendo a tutela prestacional individual medida excepcional. Estabelece que para a concessão dessa demanda, alguns preceitos devem ser observados:

1. Prévio requerimento administrativo, que pode ser suprido pela oitiva de ofício do agente público por parte do julgador; 2.Subscrição realizada por médico da rede pública ou a justificada impossibilidade; 3. Indicação do medicamento por meio da Denominação Comum Brasileira ou DCI - Internacional; 4. Justificativa da inadequação ou da inexistência de medicamento ou tratamento dispensado na rede pública; 5. E ainda laudo ou formulário ou documento subscrito pelo médico responsável pela prescrição, em que indique a necessidade do tratamento, seus efeitos, e os estudos da Medicina Baseada em Evidências, além das vantagens para o paciente, comparando-o, se houver, com eventuais fármacos ou tratamentos fornecidos pelo SUS para a mesma moléstia ${ }^{77}$.

Importante observar que a discussão coletiva promoverá um exame do contexto geral das políticas públicas discutidas, em virtude dos legitimados ativos (Ministério Público, Defensoria Pública e Associa-

76 BRASIL. Supremo Tribunal Federal. Pedido de vista adia julgamento sobre acesso a medicamentos de alto custo por via judicial. Disponível em: <http://www.stf.jus.br/portal/cms/verNoticiaDetalhe.asp?idConteudo=326275>. Acesso em: 24 set. 2017.

77 BRASIL. Supremo Tribunal Federal. Pedido de vista adia julgamento sobre acesso a medicamentos de alto custo por via judicial. Disponível em: <http://www.stf.jus.br/portal/cms/verNoticiaDetalhe.asp?idConteudo=326275>. Acesso em: 24 set. 2017. 
ções) deterem melhores condições de colacionar elementos probatórios. Isso possibilitará uma redução na quantidade de processos e uma discussão mais ampla da temática. Em contrapartida, no atual modelo de processo coletivo vigente, centrado no sistema representativo, os destinatários do provimento ficarão afastados do debate meritório. Ou seja, a invisibilidade dos sujeitos afetados pelos efeitos da decisão judicial será confirmada, considerando-se que novamente serão excluídos do debate processual. A “intensidade das indagações expostas, cabe referência à audiência pública realizada pelo STF" "78, objetivando a implementação do processo coletivo pautado no sistema participativo.

Verifica-se no entendimento do ministro Fachin entendimento hermenêutico no sentido de hierarquizar direitos fundamentais, tendo em vista que coloca o direito coletivo à saúde numa posição de destaque em relação ao direito individual à saúde. Tal posicionamento deve ser cuidadosamente analisado, uma vez que o pressuposto jurídico-democrático de que os direitos fundamentais devem ser interpretados de forma ampla e igual para todas as pessoas, incluindo-se os pacientes que necessitam de medicamento de alto custo.

No caso do RE $657.718^{79}$ que versa sobre fármacos sem registros na ANVISA e tratamentos experimentais ou paliativos, o relator Ministro Marco Aurélio explicitou a imprescindibilidade do registro ou cadastro como condição para concessão do medicamento, vez que a Agência fiscalizadora monitora a segurança, a eficácia e a qualidade terapêutica do produto. E, não havendo o registro, a inadequação é presumida e, logo, o medicamento tem a comercialização proibida, por lei, no país ${ }^{80}$.

O protagonismo judicial fica mais uma vez evidente no entendimento do relator Ministro Marco Aurélio, uma vez que cria seus próprios critérios de julgamento, ignora o diálogo com os destinatários do provimento, decidindo o caso conforme suas convicções. Para Rosemiro Pereira Leal, "essa insólita ciência do direito formadora de uma jurisprudência dos conceitos, jungida a uma jurisprudência de interesses, por uma ordem concreta de valores colhida na realidade pelo talento do decididor, é que tem dificultado o ensino jurídico pós-moderno ${ }^{81 "}$.

Barroso explicita em seu voto que, como regra geral, o Estado não pode ser obrigado a fornecer medicamentos não registrados na Anvisa por decisão judicial, já que esse registro, além de atestar a eficácia, a segurança e a qualidade dos fármacos comercializados no país, garante o devido controle de preços. Contudo, o Ministro faz ressalvas em relação aos medicamentos experimentais, sem eficácia e segurança comprovadas, que se encontram em fase de pesquisas e testes. Alega que não há nenhuma hipótese em que o Poder Judiciário possa obrigar o Estado a fornecê-los, embora eles possam ser objetos de análises em programas de testes clínicos, no caso de acesso expandido ou de uso compassivo mediante concessão administrativa nos termos da legislação aplicável ${ }^{82}$.

Novos critérios hermenêuticos são solitariamente expostos pelo julgador como ferramenta utilizada para sucumbir o exercício do direito fundamental à saúde. Privilegia-se a autoridade do decididor, que fundado em suas convicções pessoais, decide vida de inúmeras pessoas sem permitir qualquer diálogo processual com as mesmas, embora todas sofrerão os efeitos jurídicos diretos do provimento final.

No caso de medicamentos com eficácia e segurança comprovadas e testes concluídos, mas ainda sem registro na Anvisa, entende o Ministro que se trata de caso excepcional e o seu fornecimento somente poderá ocorrer quando houver irrazoável mora da Anvisa em apreciar o pedido (entendendo que o prazo seria o superior a 365 dias). Mas, três requisitos deveriam ser satisfeitos nesta hipótese: a) a existência de pedido

78 FERREIRA, Juliana Maria Matos. Teoria do Processo Coletivo no Modelo Participativo. Belo Horizonte: D’ Plácido, 2017. p. 144.

79 BRASIL. Supremo Tribunal Federal. RE 657.718. Disponível em <http://www.stf.jus.br/arquivo/cms/noticiaNoticiaStf/anexo/RE657718.pdf>. Acesso em 24 set. 2017.

80 BRASIL. Supremo Tribunal Federal. Pedido de vista adia julgamento sobre acesso a medicamentos de alto custo por via judicial. Disponível em: <http://www.stf.jus.br/portal/cms/verNoticiaDetalhe.asp?idConteudo=326275>. Acesso em: 24 set. 2017.

81 LEAL, Rosemiro Pereira. Teoria Processual da Decisão Jurídica. São Paulo: Landy, 2002. p. 66.

82 BRASIL. Supremo Tribunal Federal. Pedido de vista adia julgamento sobre acesso a medicamentos de alto custo por via judicial. Disponível em: <http://www.stf.jus.br/portal/cms/verNoticiaDetalhe.asp?idConteudo=326275>. Acesso em: 24 set. 2017. 
de registro do medicamento no Brasil; b) registro do medicamento em renomadas agências de regulação no exterior e; c) a não existência de substituto terapêutico registrado na Anvisa. E acrescenta, ainda, que o polo passivo da ação será somente a União, já que a Anvisa constitui uma autarquia federal ${ }^{83}$.

A utilização de critérios abertos, como a expressão "razoabilidade", são frequentemente mencionados nas decisões judiciais, com o condão de robustecer ideologicamente a autoridade do julgador, que não mede esforços para construir uma hermenêutica que exclui pessoas e as afastam do exercício dos direitos fundamentais expressamente previstos no plano constituinte.

Já o Ministro Fachin compreende que "na ambiência da pesquisa médica, a relação entre os pacientes e os pesquisadores é de ordem comutativa e o Estado, nesse momento peculiar, deve garantir, dentre outros, a plena autonomia da vontade do paciente e o respeito integral a seus direitos" ${ }^{\prime 4}$. Em seu entender, no âmbito da política de assistência à saúde, deve o Estado prever, como norma geral, a vedação da dispensação, do pagamento, do ressarcimento ou do reembolso de medicamento e produto, nacional ou importado, sem registro na Anvisa, isso porque as situações em que a ameaça à saúde vulnera o direito à vida, a demanda judicial toca um pedido de dignidade.

No voto do Ministro Fachin visualiza-se uma tentativa de participação dos destinatários do provimento na sua construção, algo que não ocorre, mesmo sabendo-se que o julgador mencionou rapidamente em seu voto a importância da autonomia da vontade do paciente em livremente escolher o medicamento que utilizará no seu tratamento terapêutico. A invisibilidade dos destinatários do provimento novamente se confirma, prevalecendo a hermenêutica solitária, autocrática e fundada nos parâmetros que o decididor entende mais coerentes ao caso concreto.

Apresentados esses parâmetros assinalados na jurisprudência do Supremo Tribunal Federal, passa-se a ponderação e críticas a despeito das políticas apresentadas.

\subsection{A perigosa fixação de parâmetros para casos jurídicos envolvendo a judicialização da saúde.}

Quando o Estado deixa de formular políticas públicas de saúde ou quando ele não as adimple, de forma a garantir o bem-estar físico e psíquico em favor da população, que é titular desse direito público subjetivo de estatura constitucional, incumbe-se ao Judiciário essa honrosa tarefa. Compete ao Estado a função de garantir o cumprimento das leis vigentes e a efetivação do direito fundamental à saúde e à vida.

Rafael Lorenzo-Fernandez Koatz, ao propor um debate crítico sobre a proibição do non liquet no contexto do princípio da insfastabilidade do controle jurisdicional, evidencia que o magistrado jamais poderá se esquivar de julgar um caso concreto sob o argumento de que não há comando legal para reger a situação concreta. Ou seja, a ausência de norma específica regulamentando a problemática do fornecimento estatal de medicamentos de alto custo não constitui óbice ao exercício do direito fundamental à saúde. O papel do judiciário é interpretar extensivamente os direitos fundamentais previamente previstos no plano constituinte, de modo a garantir a dignidade humana a todos. O magistrado, em qualquer instância do judiciário, tem que resolver e julgar a questão a ele submetida, interpretando-a sob a ótica do princípio da supremacia da constituição ${ }^{85}$.

Contudo, sob a premissa dos efeitos da judicialização da saúde, não pode haver a fixação de parâmetros sem basilar a estrutura concreta do caso em si. Por mais que haja similitude entre os casos, eles podem não

83 BRASIL. Supremo Tribunal Federal. Pedido de vista adia julgamento sobre acesso a medicamentos de alto custo por via judicial. Disponível em: <http://www.stf.jus.br/portal/cms/verNoticiaDetalhe.asp?idConteudo=326275>. Acesso em: 24 set. 2017.

84 BRASIL. Supremo Tribunal Federal. Pedido de vista adia julgamento sobre acesso a medicamentos de alto custo por via judicial. Disponível em: <http://www.stf.jus.br/portal/cms/verNoticiaDetalhe.asp?idConteudo=326275>. Acesso em: 24 set. 2017.

85 KOATZ, Rafael Lorenzo-Fernandez. A proibição do non liquet e o princípio da inafastabilidade do controle jurisdicional. Revista de Direito Administrativo FGV, v. 270, p. 171-205, 2015. 
ser idênticos e tratar essa matéria à luz de precedentes judiciais, julgando as demandas a partir de outros casos semelhantes, poderá causar riscos aos indivíduos quanto ao exercício do direito fundamental à saúde.

Outra questão relevante nesse contexto diz respeito à proibição de retrocesso na fundamentação jurídico-constitucional das demandas referentes aos direitos sociais. A partir das proposições trazidas por Ingo Wolfgan Sarlet ${ }^{86}$, o aumento cada vez maior de demandas por prestações sociais (demandas típicas das sociedades marcadas pelo incremento da exclusão social), frente ao decréscimo da capacidade prestacional do Estado e da sociedade, não podem ser critérios utilizados para interpretar restritivamente o direito fundamental à saúde e, assim, utilizar-se do judiciário como ferramenta de negativa de direitos já consagrados por meio de conquistas histórico-sociais. Nesse sentido, toda decisão judicial que nega o fornecimento de medicamento de alto custo, fundado na escassez de recursos estatais, exterioriza uma interpretação constitucional dos direitos fundamentais contrariamente ao princípio da proibição do retrocesso.

A demandas judiciais referentes ao direito à saúde apresentam números extravagantes, já que, segundo o Ministério da Saúde, o fornecimento de medicamentos e insumos para cumprimento de provimentos jurisdicionais passaram de cerca de $\mathrm{R} \$ 2,5$ milhões, em 2005; $\mathrm{R} \$ 266$ milhões em 2011; $\mathrm{R} \$ 843$ milhões no ano de $2014^{87}$. Mesmo diante desse cenário, o Judiciário não pode ser a instituição que limitará o exercício do direito fundamental à saúde, utilizando-se de critérios metajurídicos (aspectos econômicos e orçamentários) para justificar o indeferimento dos pedidos de medicamentos de alto custo e outros procedimentos médicos indispensáveis à dignidade humana das pessoas.

"A teoria constitucional elaborada a partir de uma constituição que contenha um sistema de normas jurídicas prevendo direitos fundamentais não está autorizada a entregar a concretização legal desses direitos à livre administração dos processos democráticos" ${ }^{88}$. Ou seja, o judiciário não pode ser visto como o recinto de exercício de ampla liberdade de interpretação dos direitos fundamentais a partir dos critérios axiológicos e metajurídicos escolhidos unilateralmente pelos julgadores. Pelo contrário, a interpretação dos direitos fundamentais no Estado Democrático deve-se pautar na premissa da inclusão e da dignidade humana. Todo direito fundamental interpretado casuisticamente para limitar, suprimir ou inviabilizar a proteção da pessoa humana contraria as proposições teórico-normativas trazidas pelo direito democrático.

Marcelo Campos Galuppo ${ }^{89}$ elucida ainda mais a temática debatida ao afirmar que "os Direitos Fundamentais representam a constitucionalização daqueles Direitos Humanos que gozaram de alto grau de justificação ao longo da história dos discursos morais, que são, por isso, reconhecidos como condições para a construção e o exercício dos demais direitos". Nesse sentido, verifica-se que os critérios hermenêuticos utilizados pelo Supremo Tribunal Federal, no que atine aos medicamentos de alto custo, sinalizam uma interpretação pautada na premissa da escassez de recursos como referencial para a interpretação restritiva do direito fundamental à saúde. Considerando-se que tal direito é líquido e certo, ao judiciário cabe o papel de determinar ao Estado o seu cumprimento como forma de assegurar aos indivíduos o exercício da cidadania e sua proteção integral. Qualquer interpretação em sentido contrário constitui afronta ao constitucionalismo democrático, reflexo de sólidas conquistas realizadas ao longo da história da humanidade.

O alto número de demandas judiciais que buscam a efetivação do direito fundamental à saúde evidencia, com clareza, a omissão estatal quanto ao tema. Fica evidente que o Legislativo e Executivo quedam-se inertes frente às suas responsabilidades primordiais e a população exige do Judiciário a efetivação de seus direitos. Em consequência, o Judiciário passa a atuar como protagonista social e as decisões individuais acabam por impactar em toda a estrutura do Estado.

86 SARLET, Ingo Wolfgang. A eficácia dos Direitos Fundamentais. 4. ed. Porto Alegre: Livraria do Advogado, 2004. p. 409-412.

87 BRASIL. Ministério da Saúde. Ações judiciais comprometem política de saúde. Brasília, 2008. Disponível em: <http://www.sinmedmg.org.br/visualizacao-de-noticias/ler/7032/acoes-judiciais-comprometem-politica-de-saude>. Acesso em: 10 set. 2017.

88 MELLO, Cláudio Ari. Democracia Constitucional e Direitos Fundamentais. Porto Alegre: Livraria do Advogado, 2004. p. 147.

89 GALUPPO, Marcelo Campos. O que são Direitos Fundamentais? Jurisdição Constitucional e Direitos Fundamentais. Coordenação José Adércio Leite Sampaio. Belo Horizonte: Del Rey, 2003. p. 233. 
"A constituição, como obra, institui a baliza normativa segundo definido pela ação do poder constituinte; por outras palavras, a constituição controla a adequação entre uma realidade fática e uma realidade normada (jurídica ${ }^{90}$. O princípio da supremacia da constituiçãa ${ }^{91}$, interpretado a partir de premissas democráticas, é o referencial racional-objetivo de entendimento do tema objeto da presente pesquisa. Qualquer interpretação restritiva no sentido de limitar o exercício do direito à saúde, fundado em argumentos atrelados à escassez de recursos públicos, constitui afronta à proposta do legislador constituinte, que trouxe no texto da constituição brasileira de 1988 proposições normativas voltadas à inclusão e proteção integral das pessoas mediante a implementação de todos os direitos fundamentais previstos no plano constituinte.

A concessão de medicamentos de alto custo é uma forma de assegurar dignidade às pessoas que não dispõe de condições econômico-financeiras de arcar com o pagamento de seu tratamento, devendo o Judiciário determinar que o Estado garanta tal direito aos seus cidadãos, indistintamente.

Repensar os mecanismos de concessão de medicamentos e tratamentos na área da saúde, especialmente os de alto custo, constitui uma medida urgente, mas há que se ter ponderação na estruturação de paradigmas, evitando-se criar estereótipos em fatores cuja caracterização não permite esse tipo de fixação. Tais afirmações justificam-se porque com a constituição brasileira de 1988

um novo marco teórico foi instituído e a partir daí o denominado Estado de Direito Democrático (art. 1., CR/88), apresentou um projeto de democracia estruturado por princípios de direitos fundamentais, com aplicação imediata (art. 5., parágrafo 1., da CR/88), e uma operacionalidade posta à disposição do cidadão (eixo desse projeto), entendido como construtor e reconstrutor do seu próprio ordenamento jurídico, por intermédio de procedimentos de participação popular e ações processuais constitucionais ${ }^{92}$.

A primeira questão a ser discutida é sobre a necessidade de se promover ações coletivas para garantia desses direitos. Isso porque a discussão coletiva promoverá um exame do contexto geral das políticas públicas discutidas, em virtude dos legitimados ativos (Ministério Público, Defensoria Pública e Associações) deterem condições de colacionar elementos probatórios para provar os fatos constitutivos do direito objeto de processo judicial.

A utilização do processo e das ações coletivas como espaço de implementação de política pública de fornecimento de medicamento de alto custo em favor de pessoas acometidas por determinadas doenças é um meio de desafogar o Judiciário, evitando-se a proliferação de demandas individuais sobre o mesmo tema. A decisão judicial proferida na ação coletiva teria efeitos erga omnes, beneficiando-se indistintamente todos os sujeitos. Nesse sentido, o processo coletivo deve ser visto como um lócus de ampla discursividade do provimento por todos os interessados difusos e coletivos, pois é um meio de concretizar o exercício dos direitos fundamentais (individuais e coletivos) previstos no plano constituinte, já que, nos dizeres de Juliana Maria Matos Ferreira ${ }^{93}$, "a técnica procedimental coletiva deve se adequar para permitir a participação dos interessados coletivos, a fim de que, pelo devido processo legal possam construir a decisão, em contraditório, que definirá o conflito de interesses existente".

Nessa perspectiva, as tutelas de prestação à saúde realizariam uma macrojustiça na medida em que na esfera coletiva há uma maior locação de recursos e possibilidades de definição de prioridades em caráter geral. A utilização da tutela coletiva é um meio de ampliar os efeitos das decisões que reconhecem o direito aos medicamentos de alto custo, tendo em vista que "é por intermédio da Constituição que o sistema da política ganha legitimidade operacional e é também por meio dela que a observância do Direito pode ser imposta de forma coercitiva" 94 .

90 PEREIRA, Rodolfo Viana. Direito Constitucional Democrático: Controle e Participação como Elementos Fundantes e Garantidores da Constitucionalidade. Rio de Janeiro: Lumen Juris, 2008.

91 DIAS, Ronaldo Brêtas de Carvalho. Processo Constitucional e Estado Democrático de Direito. Belo Horizonte: Del Rey, 2010. p. 115-118.

92 DEL NEGRI, André. Teoria da Constituição e do Direito Constitucional. Belo Horizonte: Fórum, 2009. p. 101.

93 FERREIRA, Juliana Maria Matos. Teoria do Processo Coletivo no Modelo Participativo. Belo Horizonte: D’Plácido, 2017. p. 127.

94 CARVALHO NETTO, Menelick de. A hermenêutica constitucional sob o paradigma do Estado Democrático de Direito. 
Outra questão relevante quanto ao tema em tela diz respeito à compreensão acerca da responsabilidade solidária dos entes Federativos. Embora produza impactos positivos para a concretização desses direitos, há que se vislumbrar os limites orçamentários de Municípios e alguns Estados da Federação. Por isso, a ação judicial que tem como objeto o fornecimento de medicamento de alto custo deve ser proposta em face da União, que é o ente que possui melhores condições de resguardar esse direito fundamental.

A propositura da ação judicial de fornecimento de medicamento de alto custo em face da União é uma maneira de afastar à clássica e dogmática justificativa da escassez de recursos públicos, principalmente quando a parte demandada é o município ou o estado federado. Em razão da conduta omissiva do executivo, o poder judiciário deve ser visto como o espaço que legitima a implementação de políticas públicas, tendo em vista que "no plano democrático constitucionalizado, as políticas públicas aparecem como exigências do cidadão à efetivação dos direitos fundamentalizados ${ }^{95}$ ". Ou seja, "as políticas públicas devem ser identificadas na democracia com a possibilidade de qualquer cidadão (sujeito ativo) na implantação e execução (efetivação) dos direitos fundamentalizados ${ }^{96 "}$.

No caso dos medicamentos constantes na lista do SUS, tal como ponderou os Ministros Barroso e Fachin em seus votos nos RE's 566.471 e 657.718, a concessão deve ser imediata, uma vez que já houve o exame minucioso para inserção do medicamento na tabela, não se justificando o indeferimento por fatores orçamentários. Agora, aqueles fármacos não constantes na lista deverão ser objeto de ação coletiva, de modo a evidenciar que aquele medicamento que não possui substituto terapêutico deve ser incorporado pelo SUS ou deve ser dispensado a certo grupo de pessoas que ostenta o mesmo diagnóstico, desde que provada a eficácia do medicamento pleiteado à luz da medicina baseada em evidências.

O entendimento preconizado pelos Ministros Barroso e Fachin referente aos fármacos não constantes na lista do SUS, exigindo-se a propositura de uma ação coletiva, contraria o princípio da inafastabilidade do controle jurisdicional, haja vista que limita o direito individual de acesso à justiça (ofensa ao artigo 5. Inciso XXXV Constituição brasileira de 1988). A aporia (dúvida racional acerca do critério hermenêutico utilizado) levantada evidencia a utilização de hermenêutica que restringe a interpretação do direito fundamental à saúde, suprime o direito individual de acesso à justiça, atenta contra a liberdade de escolha do paciente optar por determinado tratamento terapêutico. Ou seja, esse entendimento adotado pelo judiciário retira do jurisdicionado individualmente a possibilidade de pleitear o exercício do direito fundamental à saúde, obrigando-o a suportar a inércia e a morosidade dos legitimados ativos à ação coletiva, que nem sem atuarão no tempo e da forma adequada a proteger juridicamente paciente determinado.

A legislação brasileira esboça a imperiosidade do registro do fármaco como condição para industrialização, comercialização e importação para fins comerciais ${ }^{97}$. Nesse sentido, para que um remédio seja comercializado ou produzido no país, deve a Agência Nacional de Vigilância Sanitária, no exercício de sua competência fiscalizatória, monitorar a segurança, a eficácia e a qualidade terapêutica do produto.

Decerto que os medicamentos sem registro na Agência Nacional de Vigilância Sanitária podem implicar em sérios riscos à saúde dos pacientes, uma vez que não se trata de mero procedimento burocrático, mas de um órgão cuja função essencial pauta-se no controle, fiscalização de procedimentos e produtos inerentes à área da saúde. Para tanto, as legislações infraconstitucionais ${ }^{98}$ disciplinam os aspectos mais relevantes acerca do fornecimento de medicamentos e estabelecem os parâmetros de controle e toda a sistemática procedimental. Com isso, objetiva-se que o medicamento seja seguro, eficaz e de qualidade. Vale dizer, não apresente riscos ao ser humano, atue no combate à doença e seja fabricado mediante as observações legais. Daí essa necessidade de deferência da Agência Nacional de Vigilância Sanitária, não sendo, pois, concebível

Jurisdição e Hermenêutica Constitucional. Coordenação Marcelo Cattoni. Belo Horizonte: Mandamentos, 2004. p. 25.

95 PENNA, Saulo Versiani. Controle e Implementação Processual de Politicas Públicas no Brasil. Belo Horizonte: Fórum, 2011. p. $211-212$.

96 PENNA, Saulo Versiani. Controle e Implementação Processual de Políticas Públicas no Brasil. Belo Horizonte: Fórum, 2011. p. 215.

97 Art. 12, Lei no 6.360/1976.

98 Lei $n^{\circ} 6.360 / 1976$; Lei $n^{\circ} 8.080 / 1990 ;$ Lei $n^{\circ} 9.782 / 1999$ 
que o Estado forneça medicamentos que não estejam sob esse protocolo. Porém, a omissão estatal quanto à aprovação de comercialização pela ANVISA de determinados medicamentos não poderá constituir óbice ao direito de liberdade de escolha do paciente em buscar determinado medicamento como tratamento a sua patologia. Condicionar o tratamento médico-terapêutico escolhido pelo paciente à autorização estatal de comercialização do medicamento adequado a sua doença é uma forma de negar o direito fundamental à saúde, além de evidenciar critério de interpretação restritiva do direito fundamental à saúde.

Além desse aspecto elementar da segurança, esses medicamentos são onerosos e não necessariamente implicam em resguardar a vida do paciente; as vezes, podem se destinar a somente prolongá-la ou assegurar um tratamento paliativo. Analisando-se esse fato sob a perspectiva da dignidade da pessoa humana, esses medicamentos, ainda assim, deveriam ser concedidos, tendo em vista que a liberdade de escolha do paciente quanto ao tratamento terapêutico que adotará deve ser levado em consideração na interpretação hermenêutica do caso concreto.

A questão é o embate entre a garantia de um direito individual, mediante a concessão de medicamentos meramente paliativos, e o reflexo sobre a garantia do direito à saúde para os demais membros da coletividade. Autorizar individualmente a utilização de medicamento, cuja comercialização ainda não foi autorizada pela ANVISA, é uma forma de resguardar a liberdade de escolha do paciente quanto ao tratamento terapêutico escolhido e adequado ao seu caso.

Agora, se a não incorporação do medicamento adveio de inércia dos órgãos competentes, os quais não promoveram decisões expressas nos prazos legais, havendo falha ou demora na apreciação pela Anvisa, esses medicamentos devem ser concedidos, desde que averiguados os riscos à saúde do paciente e comprovada sua eficácia perante outros órgãos regulamentadores de outros países.

A jurisprudência sedimentada no Supremo Tribunal Federal procura estabelecer critérios objetivamente jurídicos para a análise das pretensões que buscam o fornecimento de medicamento de alto custo, utilizando-se de máximas generalizantes que desconsideram as peculiaridades de cada caso concreto. Em tais critérios, observa-se com muita evidência, que o direito fundamental à saúde ainda continua sendo visto e compreendido por esse tribunal sob o viés econômico e orçamentário, algo que contraria todas as proposições voltadas à interpretação do direito fundamental à saúde, baseado em critérios democráticos, inclusivos e extensivos.

Nesse sentido, o argumento de prevalência do direito coletivo à saúde não pode ser utilizado para suprimir a efetivação do direito fundamental e individual à saúde. Reconhecer esse argumento como válido é o mesmo que legitimar a interpretação restritiva, não sistemática, não inclusiva do direito fundamental à saúde, na contramão do princípio da dignidade humana, além de propugnar a hierarquização dos direitos coletivos face aos direitos individuais.

\section{Considerações Finais}

Os direitos fundamentais sociais transformaram-se em direitos subjetivos em sentido pleno, abarcando tutela judicial específica. Diversos casos são submetidos à apreciação judicial para que se cumpra o mister constitucional de prestação universalizada dos serviços de saúde. Embora se trate de uma verdadeira missão constitucional delegada indiretamente aos juízes e tribunais, a judicialização apresenta graves problemas advindas da falta de critérios e voluntarismos diversos de decisões irrazoadas.

Os direitos fundamentais, no texto da Constituição brasileira de 1988, são proposições teórico-legislativas que devem ser interpretados de forma sistemática, integrativa, contextualizada com o caso concreto, de modo a garantir igualmente a toda pessoa a inclusão, proteção do direito à vida, liberdade, igualdade e vedação de retrocesso. O princípio da maior extensibilidade, proposto por Joaquim Carlos Salgado, estabelece 
que o julgador deverá interpretar os direitos fundamentais da forma mais abrangente possível, de modo a garantir amplamente a inclusão e proteção jurídica da pessoa humana.

A saúde é um direito fundamental social, de dimensão individual e coletiva. Ao Estado cabe o dever de garantir a todos o acesso políticas públicas de saúde que sejam condizentes com o princípio da dignidade da pessoa humana. Argumentos econômicos, orçamentários e metajurídicos não podem ser utilizados como referenciais para o Judiciário justificar a não implementação e concretude do direito fundamental à saúde, considerando-se que se trata de direito corolário dos demais direitos fundamentais previstos no plano constituinte.

A omissão do executivo e do legislativo em implementar políticas públicas de saúde que sejam condizentes com o texto constitucional, amparando indistintamente todas as pessoas que dela precisarem, tem gerado um número significativo de ações judicial pleiteando individualmente o exercício de tal direito fundamental.

O judiciário brasileiro, visto sob a ótica da constitucionalidade democrática, tem o dever de garantir o exercício dos direitos fundamentais previstos no plano instituinte a todos aqueles cidadãos que tiveram tais direitos negados pelo Estado, sejam por meio de condutas comissivas ou omissivas.

Os critérios interpretativos que devem ser utilizados pelo judiciário quanto aos direitos fundamentais são essenciais ao entendimento crítico da temática em tela. O Supremo Tribunal Federal tem se utilizado de inúmeros critérios interpretativos dogmáticos para obstaculizar e limitar o exercício do direito fundamental à saúde. Teoria da reserva do possível; finitude dos recursos públicos; prevalência do direito coletivo frente ao individual; obrigatoriedade de comprovação pelo cidadão de que ele e sua família não dispõe de condições financeiras para arcar com o pagamento do medicamento e tratamento médico; obrigatoriedade de inclusão do medicamento no rol do Sistema Único de Saúde; obrigatoriedade de aprovação da comercialização de medicamento pela ANVISA são alguns dos inúmeros argumentos utilizados frequentemente para indeferir pedidos de fornecimento de medicamentos e demais procedimentos em favor dos cidadãos.

A liberdade do judiciário criar critérios interpretativos para limitar o exercício do direito fundamental à saúde reforça seu protagonismo e torna o exercício da jurisdição cada vez mais autocrático. Os ministros do Supremo Tribunal Federal criam solitariamente os critérios que entendem mais adequados ao julgamento das demandas referentes ao direito à saúde, assumindo um papel de legislador, limitando o acesso à saúde. No momento em que os julgadores ignoram o princípio da maior extensibilidade e vedação do retrocesso se autolegitimam na definição dos próprios critérios por eles considerados relevantes ao julgamento das demandas.

Tais decisões não gozam de democraticidade, tendo em vista que os ministros do STF não permitem qualquer participação dos interessados na construção do provimento final. O debate dos pontos controversos que integram o mérito processual limita-se ao pessoalismo e protagonismo dos julgadores, pois ignoram qualquer interlocução com os sujeitos que sofrerão diretamente os efeitos da decisão. O solipsismo, marcado por entendimentos unilaterais e autocráticos dos julgadores, é o que prevalece na interpretação restritiva do direito fundamental à saúde, certamente com a finalidade de limitar seu acesso aos cidadãos.

Sob a ótica da constitucionalidade democrática, o Estado tem o dever de fornecer medicamentos de alto custo, ressaltando-se que ao judiciário caberá a atribuição de interpretar tal direito de forma sistemática, constitucionalizada, democrática, integrativa, inclusiva e isonômica, garantindo-se a todos os cidadãos, indistintamente, o acesso à políticas públicas de saúde como corolário da dignidade humana.

\section{REFERÊNCIAS}

ALEXY, Robert. Teoria dos direitos fundamentais. Tradução de Virgílio Afonso da Silva. São Paulo: Malheiros, 
2011.

ÁVILA, Humberto. Teoria dos Princípios: da definição à aplicação dos princípios jurídicos. 4.ed. São Paulo: Malheiros, 2005.

BARCELLOS, Ana Paula de. A eficácia jurídica dos princípios constitucionais: o princípio da dignidade da pessoa humana. 3. ed. Rio de Janeiro: Renovar, 2011.

BARCELLOS, Ana Paula de. Constitucionalização das políticas públicas em matéria de direitos fundamentais: o controle politico social e o controle jurídico no espaço democrático. Revista de Direito do Estado - RDE, n. 3, p. 17-54, jul./set. 2006.

BARROSO, Luiz Roberto. Da falta de efetividade à judicialização excessiva: direito à saúde, fornecimento gratuito de medicamentos e parâmetros para a atuação judicial. Revista da Procuradoria Geral da República, Porto Alegre, v. 31, n. 66, p. 89-114, jul./dez. 2007.

BRASIL, Lei n. 6.360, de 23 de setembro de 1976. Dispõe sobre a Vigilância Sanitária a que ficam sujeitos os Medicamentos, as Drogas, os Insumos Farmacêuticos e Correlatos, Cosméticos, Saneantes e Outros Produtos, e dá outras Providências. Disponível em: < http://www.planalto.gov.br/ccivil_03/leis/L6360.htm>. Acesso em: 20 set. 2017.

BRASIL, Lei n. 8.080, de 19 de setembro de 1990. Dispõe sobre as condições para a promoção, proteção e recuperação da saúde, a organização e o funcionamento dos serviços correspondentes e dá outras providências. Disponível em: <http://www.planalto.gov.br/ccivil_03/leis/L8080.htm>. Acesso em: 20 set. 2017.

BRASIL, Supremo Tribunal Federal. Recurso Extraordinário 657718/MG. Relator: Marco Aurélio. Julgamento parcial em 15. Set. 2016b. Diário de Justiça Eletrônico, 10 jan. 2017. Disponível em: < file:///C:/Users/ Downloads/texto_97764985\%20(1).pdf>. Acesso em: 20 set. 2017.

BRASIL. Constituição (1988). Constituição da República Federativa do Brasil. 12. ed. São Paulo: Revista dos Tribunais, 2017.

BRASIL. Ministério da Saúde. Ações judiciais comprometem política de saúde. Brasília, 2008. Disponível em: $<$ http://www.sinmedmg.org.br/visualizacao-de-noticias/ler/7032/acoes-judiciais-comprometem-politicade-saude>. Acesso em: 10 set. 2017.

BRASIL. Ministério da Saúde. Gasto com 10 remédios mais pedidos na Justiça para o SUS é de quase R\$1 bi Marcelle de Souza. 6 de abril de 2017.Disponível em: <http://www.camara.gov.br/sileg/integras/1317840.pdf>. Acesso em: 20. set. 2017.

BRASIL. Supremo Tribunal Federal. Recurso Extraordinário 255627 AgR / RS. Relator Min. Nelson Jobim Diário de Justiça Eletrônico, 21 de novembro de 2000. Disponível em: < http:/ / redir.stf.jus.br/paginadorpub/ paginador.jsp?docTP $=$ AC\&docID=365054>. Acesso em: 20 set. 2017.

BRASIL. Supremo Tribunal Federal. ADPF n. 45 (BRASIL, 2004) Diário de Justiça Eletrônico Disponível em: <http://www.sbdp.org.br/arquivos/material/343_204\%20ADPF\%202045.pdf>. Acesso em: 20 set. 2017.

BRASIL. Supremo Tribunal Federal. Agravo Regimental no agravo de instrumento. n. 553.712/RS, relator, Ministro Ricardo Lewandowski, Diário de Justiça Eletrônico, 19 de maio de 2009. Disponível em: http:/ / redir. stf.jus.br/paginadorpub/paginador.jsp?docTP=AC\&docID=595522Acesso em: 20 set. 2017.

BRASIL. Supremo Tribunal Federal. Agravo Regimental no agravo de instrumento AI 238328 AgR / RS. Relator: Ministro Marco Aurélio. Diário de Justiça Eletrônico, 16 de novembro de 1999. Disponível em: < http:/ / redir.stf.jus.br/paginadorpub/paginador.jsp?docTP=AC\&docID=291210>. Acesso em: 20 set. 2017.

BRASIL. Supremo Tribunal Federal. Agravo Regimental no agravo de instrumento AI 486816 AgR / RJ, , relator Carlos Velloso Diário de Justiça Eletrônico, 12 de abril de 2005. Disponível em: < http:/ / redir.stf.jus.br/ paginadorpub/paginador.jsp?docTP=AC\&docID=459860> . Acesso em: 20 set. 2017 . 
BRASIL. Supremo Tribunal Federal. Agravo Regimental no agravo de instrumento AI 597182 AgR / RS. Relator Min. Cézar Peluso. Diário de Justiça Eletrônico 10 de outrubro de 2006, Disponível em: <http:/ / redir. stf.jus.br/paginadorpub/paginador.jsp?docTP=AC\&docID=390282>. Acesso em: 20 set. 2017.

BRASIL. Supremo Tribunal Federal. Agravo Regimental, Suspenção de tutela antecipada 175/CE. Relator: Gilmar Mendes. Diário de Justiça Eletrônico, 24 jun. 2009. Disponível em: <http://www.stf.jus.br/arquivo/ cms/noticianoticiastf/anexo/sta175.pdf>. Acesso em:10 set. 2017.

BRASIL. Supremo Tribunal Federal. Audiência Pública n. 4. Brasília, 24 abr. 2009. Disponível em: <http:// www.stf.jus.br/arquivo/cms/processoAudienciaPublica>. Acesso em: 14 set. 2017.

BRASIL. Supremo Tribunal Federal. Disponível em: <http://www.stf.jus.br/portal/cms/verNoticiaDetalhe.asp?idConteudo=326275>. Acesso em: 24 set. 2017.

BRASIL. Supremo Tribunal Federal. Poder Público deve custear medicamentos e tratamentos de alto custo a portadores de doenças graves, decide o Plenário do STF. Disponível em: < http://www.stf.jus.br/portal/cms/verNoticiaDetalhe. asp?idConteudo=122125>. Acesso em 24 set. 2017.

BRASIL. Supremo Tribunal Federal. RE 566.471. Disponível em <http://redir.stf.jus.br/paginadorpub/ paginador.jsp?docTP=TP\&docID=12071365>. Acesso em: 24 set. 2017.

BRASIL. Supremo Tribunal Federal. RE 657.718. Disponível em <http://www.stf.jus.br/arquivo/cms/ noticiaNoticiaStf/anexo/RE657718.pdf>. Acesso em 24 set. 2017.

BRASIL. Supremo Tribunal Federal. Recurso Extraordinário 566.471/RN. Relator: Marco Aurélio. Diário de Justiça Eletrônico, 15. Set. 2016a. Disponível em: < file:///C:/Users/Downloads/texto_97764985\%20(1). pdf $>$. Acesso em: 20 set. 2017.

BRASIL. Supremo Tribunal Federal. Recurso Extraordinário n. 195192/RS. Relator: Marco Aurélio. Diário de Justiça Eletrônico, 31 de mar. 2000. Disponível em: < http://redir.stf.jus.br/paginadorpub/paginador. jsp?docTP=AC\&docID=234359>.Acesso em: 20 set. 2017.

BRASIL. Supremo Tribunal Federal. Suspensão da Tutela Antecipada STA 91/AL. Disponível em: <https:// stf.jusbrasil.com.br/jurisprudencia/19139898/suspensao-de-tutela-antecipada-sta-91-al-stf>. Acesso em: 24 set. 2017.

CANOTILHO, Joaquim José Gomes. Direito Constitucional e Teoria da Constituição. 7 ed. Coimbra: Almedina, 2003.

CARVALHO FILHO, José dos Santos. Políticas públicas e pretensões judiciais determinativas: IN: FORTINI, Cristiana; ESTEVES, Júlio C. Santos; DIAS, Maria Tereza Fonseca (Org.). Políticas públicas: possibilidades e limites. Belo Horizonte: Fórum, 2008.

CARVALHO NETTO, Menelick de. A hermenêutica constitucional sob o paradigma do Estado Democrático de Direito. Jurisdição e Hermenêutica Constitucional. Coordenação Marcelo Cattoni. Belo Horizonte: Mandamentos, 2004.

CHAMON JUNIOR, Lúcio Antônio. Terium Non Datur: pretensões de coercibilidade e validade em face de uma Teoria da Argumentação Jurídica no marco de uma compreensão procedimental do Estado Democrático de Direito. Jurisdição e Hermenêtitica Constitucional. Coordenação Marcelo Cattoni. Belo Horizonte: Mandamentos, 2004.

CONSELHO NACIONAL DE JUSTIÇA. Judicialização da saúde no Brasil: dados e experiência. Coordenadores: Felipe Dutra Asensi e Roseni Pinheiro. Brasília: Conselho Nacional de Justiça, 2015.

CONSELHO NACIONAL DE JUSTIÇA. Resolução nº 107 de 2010. Institui o Fórum Nacional do Judiciário para monitoramento e resolução das demandas de assistência à saúde. Disponível em: <http://www.cnj.jus. br/images/stories/docscnj/resolucao /rescnj_107.pdf>. Acesso em: 14 nov. 2016. 
DEL NEGRI, André. Teoria da Constituição e do Direito Constitucional. Belo Horizonte: Fórum, 2009.

DIAS, Maria Socorro de Araújo et al. Judicialização da saúde pública brasileira. 135. Revista Brasileira de Políticas Públicas, v. 6, n. 2, out. 2016. Disponível em <file://C:/Users/Fabricio/Downloads/4012-19241-1-PB. pdf>. Acesso em 09 out. 2017.

DIAS, Ronaldo Brêtas de Carvalho. Processo Constitucional e Estado Democrático de Direito. Belo Horizonte: Del Rey, 2010.

FARO, Júlio Pinheiro. Políticas públicas, deveres fundamentais e concretização de direitos. Revista Brasileira de Políticas Públicas, v. 3, n. 2, jul./dez. 2013. Disponível em: < file:// /C:/Users/Fabricio/Downloads/216112654-1-PB.pdf>. Acesso em: 09 out. 2017.

FERREIRA, Juliana Maria Matos. Teoria do Processo Coletivo no Modelo Participativo. Belo Horizonte: D’Plácido.

FIORILLO, Celso Antonio Pacheco. Curso de direito ambiental brasileiro. 12. ed. rev. atual. e ampl. São Paulo: Saraiva, 2011.

GALUPPO, Marcelo Campos. O que são Direitos Fundamentais? Jurisdição Constitucional e Direitos Fundamentais. Coordenação José Adércio Leite Sampaio. Belo Horizonte: Del Rey, 2003.

GUERRA FILHO, Wilis Santiago. Direitos Fundamentais, processo e princípio da proporcionalidade. Dos Direitos Fundamentais aos Direitos Humanos. Porto Alegre: Livraria do Advogado, 1997.

KANT, Immanuel. Fundamentação da metafísica dos costumes. Tradução de Leopoldo Halzbach. São Paulo: Martin Claret, 2003.

KOATZ, Rafael Lorenzo-Fernandez. A proibição do non liquet e o princípio da inafastabilidade do controle jurisdicional. Revista de Direito Administrativo FGV, v. 270, p. 171-205, 2015.

LEAL, Rosemiro Pereira. Teoria Processual da Decisão Jurídica. São Paulo: Landy, 2002.

MACHADO, Tereza Robichez de Carvalho. Judicialização da saúde: analisando a audiência pública no Supremo Tribunal Federal. Revista de Bioética, p. 561-568, 2014. Disponível em: <http://www.scielo.br/pdf/ bioet/v22n3/v22n3a20.pdf>. Acesso em: 24 set. 2017.

MACIEL JUNIOR, Vicente de Paula. Teoria das Ações Coletivas: as ações coletivas como ações temáticas. São Paulo: Ltr, 2006.

MARTINS, Urá Lobato. A judicialização das políticas públicas e o direito subjetivo individual à saúde, à luz da teoria da justiça distributiva de John Rawls. Revista Brasileira de Políticas Públicas, v. 5, Número Especial, 2015. Disponível em: <file:///C:/Users/Fabricio/Downloads/3020-15496-1-PB.pdf>. Acesso em: 09 out. 2017.

MATIAS, João Luis Nogueira; MUNIZ, Águeda. O poder judiciário e a efetivação do direito à saúde. Revista Brasileira de Políticas Públicas, v. 5, n. 1, jan./jun. 2015. Disponível em: < file:///C:/Users/Fabricio/ Downloads/3377-15381-2-PB.pdf>. Acesso em: 09 out. 2017.

MELLO, Cláudio Ari. Democracia Constitucional e Direitos Fundamentais. Porto Alegre: Livraria do Advogado, 2004.

MELO, José Tarcísio de Almeida. Direito Constitucional do Brasil. 30. ed. rev e atual. Belo Horizonte: Del Rey, 2014.

MOREIRA, Bárbara Antonina E. de Campos; FERNANDES, Bianca de Menezes; RIBEIRO, Brenda Senna Guimarães. O direito à saúde sob a ótica da hermenêutica dos direitos fundamentais. In: DAMASCENO, Maria Helena; MEGALE, Silva (Org.). Horizontes Hermenêuticos. Belo Horizonte: Imprensa Universitária da UFMG, 2012. 
MOREIRA, Eduardo Ribeiro. A possibilidade de controle judicial das políticas públicas. In: FIGUEIREDO, Marcelo. (Coord.). Novos Rumos para o Direito Público - Reflexões em Homenagem à professora Lúcia Valle Figueiredo. Belo Horizonte: Fórum, 2012.

MOURA, Emerson Affonso da Costa Moura; ORDACGY, Fabrizia da Fonseca Passos Bittencourt. Direito à Saúde, políticas públicas do Sistema Único de Saúde e acesso ao serviço público hospital e ambulatorial. Revista Brasileira de Políticas Públicas. v. 4, n. 1, jan./jun. 2014. Disponível em: < file:///C:/Users/Fabricio/ Downloads/2628-13625-1-PB.pdf>. Acesso em: 09 out. 2017.

NOGUEIRA, Marcia Coli. Medicamentos sem registro: legislação, causas para a demanda, danos à saúde e consequências para a gestão. Brasília: Conselho Nacional de Secretários de Saúde - CONASS, 2015. Col. Para entender a gestão do SUS.

NUNES, José Avelãs; SCARFF, Fernando Facury. Os tribunais e o direito à saúde. Porto Alegre: Livraria do Advogado,2011.

PENNA, Saulo Versiani. Controle e Implementação Processual de Políticas Públicas no Brasil. Belo Horizonte: Fórum, 2011.

PEPE, Vera Lúcia Edais et al. A judicialização da saúde e os novos desafios da gestão da assistência farmacêutica. Revista Ciência e Saúde Coletiva, v. 5, n. 15, p. 2405-2414, abr. 2010. Disponível em: <http://www. scielo.br/pdf/csc/v15n5/v15n5a15>. Acesso em: 10 set. 2017.

PEREIRA, Fernanda Tercetti Nunes. Ativismo Judicial e Direito à Saúde: a judicialização das políticas públicas de saúde e os impactos da postura ativista do Poder Judiciário. Revista Brasileira de Políticas Públicas. v. 5, Número Especial, 2015. Disponível em: <file://C:/Users/Fabricio/Downloads/3096-15493-1-PB.pdf>. Acesso em: 09 out. 2017.

PEREIRA, Rodolfo Viana. Direito Constitucional Democrático: Controle e Participação como Elementos Fundantes e Garantidores da Constitucionalidade. Rio de Janeiro: Lumen Juris, 2008.

POMPEU, Carolina. Gastos da União com demandas judiciais de saúde crescem 500\%. 15 de abril de 2015. Disponível em: <http://www.gazetadopovo.com.br/vida-e-cidadania/gastos-da-uniao-com-demandas-judiciais-de-saude-crescem-500-439sjmi7gq0wwarfocypk15tl>. Acesso em: 20 set. 2017

ROCHA, Aristides Almeida; CESAR, Chester Luiz Galvão; RIBEIRO, Helena. Saúde Pública: Bases conceituais. 2. ed. São Paulo: Atheneu, 2013.

SARLET, Ingo Wolfgang. A eficácia dos Direitos Fundamentais. 4. ed. Porto Alegre: Livraria do Advogado, 2004.

SARLET, Ingo Wolfgang. Dignidade da pessoa humana e direitos fundamentas na Constituição Federal de 1988. Porto Alegre: Livraria do Advogado, 2001.

SARMENTO, Daniel. Direitos fundamentais e relações privadas. 2. ed. Rio de Janeiro: Lumem Juris, 2008.

SILVA, Virgílio Afonso da. A constitucionalização do direito: os direitos fundamentais nas relações entre particulares. São Paulo: Mandamentos, 2008.

STRECK, Lenio Luiz. O que é isto: decido conforme minha consciência? Porto Alegre: Livraria do Advogado, 2012. 
Para publicar na revista Brasileira de Políticas Públicas, acesse o endereço eletrônico www.rbpp.uniceub.br

Observe as normas de publicação, para facilitar e agilizar o trabalho de edição. 